\title{
Employee Motivation and Work Performance: A Comparative Study of Mining Companies in Ghana
}

\author{
Elizabeth Boye Kuranchie-Mensah ${ }^{1}$ (D), Kwesi Amponsah-Tawiah² \\ ${ }^{1}$ University for Development Studies, ${ }^{2}$ University of Ghana (Ghana) \\ ekurancbie@uds.edu.gh, k_amponsah-tawiah@ug.edu.gh
}

Received: June 2015

Accepted: December 2015

\section{Abstract:}

Purpose: The paper empirically compares employee motivation and its impact on performance in Ghanaian Mining Companies, where in measuring performance, the job satisfaction model is used.

Design/methodology/approach: The study employed exploratory research design in gathering data from four large-scale Gold mining companies in Ghana with regards to their policies and structures in the effectiveness of motivational tools and strategies used by these companies.

Findings: The study observed that, due to the risk factors associated with the mining industry, management has to ensure that employees are well motivated to curb the rate at which employees embark on industrial unrest which affect performance, and employees are to comply with health and safety rules because the industry contribute hugely to the Gross Domestic Product (GDP) of the country.

Research limitations/implications: Limitation to the present study include the researcher's inability to contact other mining companies. However, the study suggests possibilities for future research including contacting other mining companies, expanding the sample size, managers ensuring that the safety and health needs of staff are addressed particularly those exposed to toxic and harmful chemicals. 
Originality/value: A lot of studies have been done on mining companies in the past. This paper fills a gap perceived that employees in this sector are highly motivated in spite of the challenges being faced by them, and knowing more about what keeps employees moving is still of national interest.

Keywords: employee motivation, performance, satisfaction, Mining Company Dynamics

\section{Introduction}

The staff of any industry are key resources to that industry's success. Human asset in the $21^{\text {st }}$ century is considered the most important asset of any company (Hafiza, Shah, Jamsheed \& Zaman, 2011). Mining staff, in particular, account for a significant component of the budget of higher productive institutions and has a major role to play in achieving the objectives of the industry.

Gold mining is one of the key areas of natural resources that is often argued to have the potential of boosting a country's economy through the attraction of direct foreign investment (Hilson \& Banchirigah, 2009). "Gold is the largest contributor to the economy, accounting for about $38 \%$ of total merchandise and $95 \%$ of total mineral export as well as about $80 \%$ of all mineral revenue" (Garvin, Mcgee, Smoyer-Tomic \& Aubynn, 2009: page 572).

The performance of mining staff (employees), as well as managers, determines to a large extent, the quality of employees' as expressed by Hellriegel and Slocum (2007: page 55) that, "Low job satisfaction can result in costly turnover, absenteeism, tardiness, and even poor mental health". This is further argued by Kreisman (2002) that the most valuable and volatile asset of any institution is a well- motivated and stable workforce which is competent, dedicated and productive.

According to Gallagher and Einhorn (1976), whether supervising an expansion of a firm's activities, or cutting back on policies in response to sagging demand, a manager continually strives to draw a better return on his capital investment. When this effort is directed toward the human portion of the firm's capital, the manager focuses on a recurrent problem in business activity -"employee motivation".

Since all organizations are concerned with what should be done to achieve sustained high levels of performance through people, it means giving close attention to how individuals can best be motivated through such means as incentives, rewards and importantly, the work they do and the organisation context within which they carry out that work cannot be understated (Armstrong, 2010). Without increased motivation and morale of the employees, the 
organisation risks losing valuable employees and will be at a disadvantage in attracting potential top talents (Dessler, 2003).

Rewards can serve the purpose of attracting prospective job applicants, achieving human resource objectives and obtaining competitive advantage (Bratton \& Gold, 2007). This is particularly important in a competitive hybrid sector where the mining companies are struggling for high-caliber employees in order to improve the quality of work and gaining excellent reputation.

Caruth and Handlogten (2002) also specified that reward systems most especially are considered as forerunners of employee motivation. Since employees' knowledge, skills and abilities are the most important driving force to the success of any organization, continuing commitment and support to them could be realized through looking for effective ways to reward their contributions, loyalty, dedication and efforts.

According to Hafiza et al. (2011), there are several factors that can affect employee performance like training and development opportunities, working conditions, worker-employer relationship, job security and company over all policies and procedures for rewarding employees. Among the factors that affect employee performance, motivation that comes with rewards is of utmost importance (Carraher, Gibbson \& Buckley, 2006).

Motivation is defined as the process that accounts for an individual's intensity, direction and persistence of effort toward attaining a goal (Page, 2008). According to Tosi, Mero and Rizzo (2000), motivation has both psychological and managerial meaning. The psychological meaning of motivation refers to the internal mental state of a person that relates to the initiation, direction, persistence, intensity and termination of behaviour. The managerial meaning of motivation on the other hand deals with the activity of managers and leaders to induce others in order to produce results desired or outlined by the organization or by the manager which conforms to a relationship between motivation, ability and performance.

Since there is a wide variety of methods available for motivating staff, from recognizing the employee's achievements by simply saying "thank you" to more complex schemes which combine and set targets with fixed rewards (Torrington, Hall \& Taylor, 2008), it will however look ridiculous for the team responsible for motivation in the mining companies to attempt to motivate their employees when they don't know what motivates the employees.

Motivation of employees in the work place still remains one of the sensitive subjects that determine the level of input that employees will put in the organization to commit to good performance. This means that motivation either intrinsic or extrinsic contribute to employee satisfaction and thus enhances performance and productivity (Bhattacharyya, 2007) and it is expressed by Lawler (2003) that in the twenty-first century, treating people right is not an option but a necessity. This was emphasized by Dreher and Dougherty (2002) that, the way a 
company manages its workforce determines its ability to establish and maintain a competitive advantage over other companies.

\subsection{Statement of the Problem}

Work, being formal or informal, paid or unpaid, plays a central role in the lives of people all across the world. Through work, men and women define themselves and their roles in society. Yet while many jobs provide both income and personal satisfaction, they may also pose hazards and risks to health and safety.

Among the public and private sector institutions in Ghana, the mining industry can be seen as one of the oldest industries known to play a central role in the economic development of the country. Yet the mining industry has a problem of health-related illnesses and diseases where miners are exposed to various toxic and harmful materials, including fuels, reagents, chemicals, noise, poisonous gases and metal dust. Despite considerable efforts in many countries, the toll of death, injury and disease among the world's mineworkers shows that this sector remains extremely hazardous (ILO, Global Employment Trends for Women in March, 2005).

Increasing number of workers in the USA, Canada, UK, Germany and other industrialized countries are now suffering and dying from past exposure to asbestos dust. Silicosis - a fatal lung disease caused by exposure to silica dust - still affects millions of miners around the world (Akabzaa, 2009). Occupational health is an important strategy not only to ensure the health of workers, but also to contribute positively to productivity, quality of products, work motivation, work performance and thereby the overall quality of life of individuals and society (WHO, 1994).

Health at work and healthy work environment are among the most valuable assets of individuals, communities and countries (Amponsah-Tawiah \& Dartey-Baah, 2011). The indications that the continued development of the industry and the transformation of the rich mineral resources into a sustainable economic development will help satisfy the social and economic needs of employees. The gap to be filled in the study is to find out what really motivates employees in the mining industry. The answer to this question might be of relevance to HR professionals and managers who are responsible for preparing reward and motivation schemes for their companies and know what interest them.

A study by Wittmer (1991) indicated that there are significant differences between the public and private sector irrespective of managers' values and reward preferences. Private sector workers are more likely to be motivated by monetary rewards than public sector managers, whereas other organizational motivation factors (promotion, prestige, co-worker friendship, and opportunities for public service) are not significantly different between sectors (Wittmer, 1991). 
Numerous studies (for instance: Akabzaa, 2009; Amponsah-Tawiah \& Dartey-Baah, 2010; Aryee, 2001; Bloch \& Owusu, 2011; Sanda \& Adjei-Benin, 2011) have been conducted in the mining industry but not on employee motivation. Since it is perceived that employees in this sector are highly motivated in spite of the challenges being faced by them, knowing more about what keeps employees moving is still of national interest.

Mining sector workers are most often than not specialised individuals who gain knowledge from an academic institution that provide information on mining, so individuals with expertise in the mining sector hardly leave the sector to a non- mining institution or industry. As a result of that, management's response to organisational effectiveness and performance is mostly defined within the institution.

In September 2009, the management and workers at South African miners Goldfields' Tarkwa gold mine in Ghana threatened to embark on a go-slow strike because of pay dispute. In a similar situation, employees at AngloGold Ashanti also embarked on a strike action over pay and working conditions which was confirmed that underground work reduced to minimal level. Employees at Newmont Ghana Ltd. also embarked on strike action at their management for delay in paying their bonuses and allowances which were supposed to be paid to them (Ogola, Mutuilah \& Omulo, 2002).

Since motivated employees are a great asset to any organisation, and most research works have been conducted in the public sector, this study therefore focuses on a hybrid form of organisation like the mining industry where government and private individuals have a stake in its operations. The industry contributes 5\% to the country's Gross Domestic Product (GDP) and minerals make up $37 \%$ of total exports, of which gold contributes over $90 \%$ of the total mineral exports. So far as mining operation is still important to national development, it is essential to compare employee motivation and its impact on performance within the industry by identifying what really motivates them and keep them going in the industry as it is perceived employees within these industries are highly motivated.

Therefore, the study seeks to identify the best motivating factor for the employees in the large scale gold mining industries in Ghana that will ensure that miners have a work environment with the characteristics of work known to be linked to motivation and performance.

The aim of the study is in twofold. First, it is to find out how intrinsic and extrinsic motivation impact on work performance. Secondly, it is to assess the motivational needs from the perspective of employees of Ghanaian Mining Companies. The study seeks to test the following hypotheses:

$\boldsymbol{H}_{1}$ : There is a significant relationship between intrinsic motivation and work performance. 
$\boldsymbol{H}_{2}$ : There is a significant relationship between extrinsic motivation and work performance.

$\boldsymbol{H}_{3}$ : There is a significant difference in motivation across age of employees in the Mining Companies in Ghana.

\subsection{Conceptual Framework}

Theorists such as Maslow (1954), Herzberg, Mausner and Snyderman (1959), and Alderfer (1972), have sought to explain employee motivation by holding on to the assumption that all individuals possess the same set of needs and therefore prescribe the characteristics that ought to be present in the jobs. These theorists have afforded opportunities to managers to design motivational schemes to influence performance. What need to be answered are the factors of motivation which drive the performance of employees in the mining sectors of Ghana. Though managers and organisations have applied motivation theories to the same behaviour in different countries and institutions, the growing realisation that traditional models of motivation do not explain the diversity of behaviours found in organisational settings have brought to fore the need for a socially sensitive approach in the Ghanaian context.

Motivation is therefore about what a person wants and about his emotional state, which drives him in the direction of achieving what he wants (Mullins, 2010). The conceptual approach to motivation is therefore based on the idea that individual needs or expectation results in the behaviour or action that drives him or her to achieve desired goals which provide fulfilment in the individual.

Rotter (1966) suggests that the occurrence of a particular behaviour is dependent not only on an individual's objective reinforcement history (the behaviourist view), but also on the individual's expectation that the behaviour will result in a particular consequence and the subjective assessment of the costs and benefits associated with the consequence (the cognitivist view). As Porter and Lawler (1968) posits, mere effort is not enough and before the effort will be effective, it has to produce the desired performance. These constructs are readily recognizable in the expectancy theory conception of motivation, which provides the theoretical linkage between motivation and performance underlying the choice of the criterion variable used in this study (Ramlall, 2004).

This is illustrated in the Figure 1 below: 


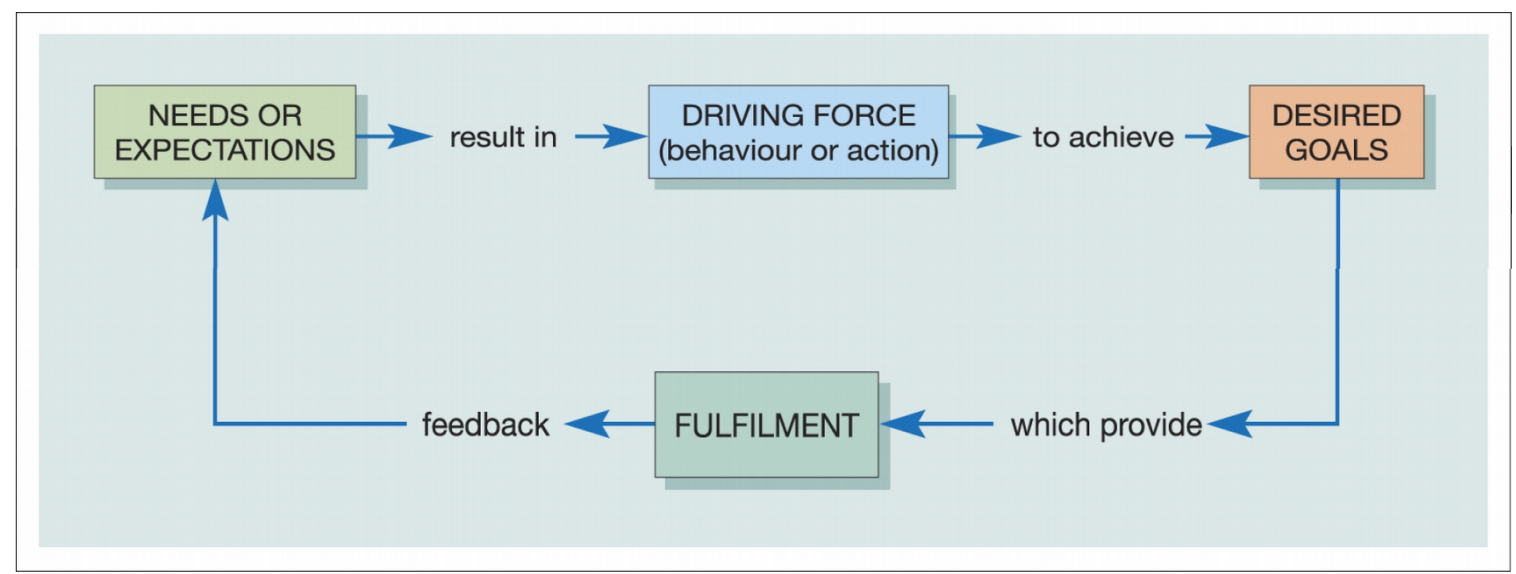

Figure 1. Conceptual Framework (Mullins, 2010)

\subsection{Significance of the Study}

There are four important ways in which this study will be of importance and add to collective research literature. First of all, it will provide much insight into the work lives of mine workers with regard to employees' level of motivation and performance because a good motivational procedure is essential to achieve organizations' goal. Effective motivational programmes of employees can achieve efficiency to develop a good organizational culture.

Secondly, it may assist mining industries in retaining, satisfying, and attracting qualified employees since motivation has variety of effects which may be seen in the context of an individual's physical and mental health, productivity, absenteeism and turnover. Employee delight has to be managed in more than one way. This helps in retaining and nurturing the true believers who can deliver value to the organization.

Thirdly, it will also reveal interesting insight into the importance of employee motivation and impact on work performance for the other mining companies and they may use this as a guide when motivating their employees.

Fourthly, it will generate data that may be used to develop a model to prompt further research regarding strategic guidance for mining companies that are both providing and using reward and recognition programs. 


\section{Literature Review}

\subsection{Origin of Motivation}

In the early 20th century, money was regarded as the most important input into the production of goods and services (Kreitner, 1995). However, after a series of researches, one known to be the "Hawthorne Studies", conducted by Elton Mayo from 1924-1932 at the Hawthorne Works of the American Western Electric Company in Chicago, it was observed that employees were not motivated solely by money but that employee behavior was linked to their attitudes (Dickson, 1973, in Lindner, 1998). The Hawthorne studies began the human relations approach to management, whereby the needs and motivation of employees become the primary focus of managers (Bedeian, 1993). This paved way for other theories and definitions on motivation and performance at the work place.

\subsection{Definition of Motivation}

There have been various definitions of motivation across different disciplines in the academia ranging from the fields of management, psychology to allied sciences. According to Kreitner and Kinicki (1998) and Ramlall (2004), motivation is derived from the Latin word "movere" which means to move. Butkus and Green (1999) also stated that motivation is derived from the word "motivate" which also means to move, push or persuade to act to satisfy a need.

However, Mol (1992) differentiated between the terms "movement" and "motivation". Mol (1992) described movement as carrying out a task in order to be compensated or remunerated while motivation is the voluntary involvement, and decision of a person to carry out a task.

Page (2008) in his article on non-monetary incentives in the workplace defined motivation as the process that accounts for an individual's intensity, direction and persistence of effort toward attaining a goal. In Cole (1996), motivation is essentially about what drives a person to work in a particular way and with a given amount of effort.

Motivation has been defined as 'a decision making process through which the individual chooses desired outcomes and sets in motion the behaviours appropriate to acquiring them' (Huczynski \& Buchanan,1991, in Dartey-Baah, 2010). Lindner (2004) also sees motivation as a psychological process that gives behaviour purpose, purpose and direction.

Robbins (2005) defined motivation as the "willingness to exert high levels of effort toward organisational goals, conditioned by the effort's ability to satisfy some individual need". According to Robbins (2005), a need is an internal state that makes certain outcomes appears attractive and an unsatisfied need creates tension that stimulates drives within an individual. 
These drives generate search behaviour to find goals that if attained, will satisfy the need and lead to the reduction of tension (Robbins, 2005).

Baron (1983, in Mol, 1992) also defined motivation as a set of processes concerned with a kind of force that energizes behaviour and directs it towards achieving specific goals. It further states that not only motivation can influence performance, but that performance can also influence motivation, if followed by rewards. Carraher et al. (2006) advocates that there should be an effective reward system to retain the high performers in organizations and reward should be related to their productivity. Baron (1983) therefore concludes organizations could benefit from implementing total reward programmes that focus on formal reward policies.

Shah and Shah (2010) defined motivation as inspiring people to work; individually or in groups in such a way as to produce best results. It further states that, motivation is a general term applied to the entire class of drives, desires, needs, wishes and similar forces. Shah and Shah (2010) noted that to say that managers motivate their subordinates is to say that they do those things which they hope will satisfy these drives and desires and induce the subordinates to act in a desired manner.

\subsection{Motivation Process and Strategies}

Motivation is explained by various theorists as a process governing choices (Bhattarcharyya, 2009). The motivation process may be internal or external to the individual that arouses enthusiasm, and persistence to pursue a certain course of action.

The motivation process starts with a physiological or psychological deficiency or need that activates behaviour, or a drive that is aimed at a goal (Bhattarcharyya, 2009). According to Arnold, Robertson and Cooper (1991), a needs-related model of the process of motivation is initiated by the conscious or unconscious recognition of unsatisfied needs. The needs create wants, which are desires to achieve or obtain something. Goals are established which is believed will satisfy the needs and wants, and a behaviour pathway is selected which is expected to achieve the goal (Armstrong, 2010).

According to Palmer (2005), a fundamental part of a motivation strategy must be that the process of achieving the goal is itself motivational. In other words, it is important to ensure that people do not give up during the implementation phase, by designing a process for achieving goals, and to control the motivation strategy.

A motivation strategy is necessary for conducting the daily tasks and motivating employees with common goals. It is not only a decision or simple words used to describe the goal, but also using a set of skills to achieve it (Palmer, 2005). From the organisational point of view, the 
motivation process follows certain defined steps, which, as a continuum needs to be periodically reviewed and strategized to ensure its proper renewal (Green, 2000). This helps to maintain the motivation of employees.

Herzberg et al. (1959) proposed that an employee's motivation to work is best understood when the respective attitude of that employee is understood. That is, the internal concept of attitude which originates from a state of mind, when probed, should reveal the most pragmatic information for managers with regard to the motivation of workers.

\subsection{Types of Motivation}

Work motivation is mostly categorized into two types, being intrinsic and extrinsic motivation showing that different incentives have a distinct impact on employee motivation. Whereas intrinsic motivation is concerned with rewards as the activity itself, the source of extrinsic motivation are external controlling variables as explicit rewards (e.g. money, threat) (Herzberg, 2003; Cameron \& Pierce, 2002).

McCullagh (2005) defines intrinsic motivation as an individuals' need to feel competency and pride in something while extrinsic motivation is defined as the performance of an activity in order to attain some separate outcome and noted that, people can be both intrinsically and extrinsically motivated.

Hackman and Oldham (1980) argued that strong intrinsic motivation occur when three psychological states are created, and these are:

- experienced meaningfulness of the work,

- experienced responsibility for outcomes of the work, and

- Knowledge of the actual results of the work activities.

Hackman and Oldham (1980) urged organizations to restructure work to induce intrinsic motivation. Greater skill variety, task identity, and task significance increase the experienced meaningfulness of work, autonomy raises experienced responsibility, and feedback provides knowledge of results (Hackman \& Oldham, 1980).

According to the self-determination theory, intrinsic motivation is increased in more autonomous work situations and results in more positive attitudinal and behavioural outcomes (Deci \& Ryan, 1985; Ryan \& Connell, 1989). Against Frey's (1997) work on motivation, it leads to the argument that external rewards crowd out intrinsic motivation and reduce the individual's work effort because of incentives which are in conflict with the employee's moral values and choices. Contrary to that, external rewards can help crowd in intrinsic motivation when supporting the employee's choices and values. 
Intrinsic motivation, captures the aspects of doing work for its own sake (Osterloh, Frost \& Frey, 2002; Ryan \& Deci, 2000), provides psychological benefits of well-being (Ryan \& Deci, 2000), accomplishment (Dermer, 1975), increasing responsibility (Kohn, 1993; Herzberg, 2003), self-actualisation (Kunz \& Pfaff, 2002), and is self-sustaining (Osterloh et al., 2002).

A number of authors argue that money is a poor motivator and can actually impede intrinsic motivation, such as reducing creativity and innovation (Osterloh et al., 2002; Herzberg, 2003). Contrary to that, Bishop (1987) suggested that pay is directly related with productivity and reward system depends upon the size of an organization.

The specific focus on extrinsic motivation may distract attention from the task which has been termed as hidden cost of rewards. This view has been incorporated in the crowding theory (Osterloh et al., 2002).

When an activity is intrinsically appealing (say, challenging), the positive effects can be undermined if extrinsic rewards are also linked to the activity (Osterloh et al., 2002) and crowd out intrinsic motivation (Lee \& Whitford, 2007). This crowding out has been further elaborated under the cognitive evaluation theory, which proposes that extrinsic motivation can erode intrinsic motivation (Kunz \& Pfaff, 2002).

Reio and Callahon (2004) further concludes that both intrinsic and extrinsic rewards motivates the employee resulted in higher productivity.

\subsection{Theories on Employee Motivation}

Many theories have been propounded to examine the factors that contribute to employee motivation in organizations. These theories are important because they provide explanations to the reasons why employees are motivated, therefore, if properly applied, could lead to having better motivated employees which ultimately may lead to increased productivity in organizations (McCullagh, 2005).

The earliest motivation theories (pre-1960s) include, among others, Abraham Maslow's hierarchy of need theory (Maslow, 1954); Homans (1950), Fredrick Herzberg's two-factor theory (Herzberg et al., 1959), and B.F. Skinner's reinforcement theory (Skinner, 1953). According to Armstrong (2010), these theories have led to the understanding of motivation and are underpinned by motivation theory classified as Instrumentality theory, Content theory and Process theory.

According to Armstrong (2010), in understanding and applying motivation theory, the aim is to obtain added value through people in the sense that the value of their output exceeds the cost 
of generating it, and it can be achieved through unrestricted effort which is a key component in organisational performance.

Based on Mullin's (2010) model of motivation, various theories of employee motivation are discussed, including Skinner's Reinforcement theory (Skinner, 1953), Maslow's hierarchy of needs theory (Maslow, 1954), Herzberg's two-factor theory (Herzberg et al., 1959), Vroom's expectancy theory (Vroom, 1964), Locke and Latham's goal achievement theory (Locke \& Latham, 2004) and Adam's equity theory (Adams, 1965). These theories attempt to explain employees' behaviour and provide understanding to both managers and employees of how to motivate others and become more involved in one's own motivation (Drafke \& Kossen, 2002).

\subsubsection{Instrumentality Theory}

The theory emerged in the second half of the nineteenth century with its emphasis on the need to rationalise work, and also on economic outcomes (Armstrong, 1999). It assumes that a person will be motivated to work if rewards and penalties are tied directly to the individuals' performance, thus the awards are contingent upon effective performance; meaning, people only work for money.

Instrumentality theory states that rewards or punishment serve as the means of ensuring that people behave or act in desired ways which is based on the principle of reinforcement as influenced by Skinner (1974) concept of conditioning- the theory that, people can be "conditioned" to act in certain ways if they were rewarded for behaving as required.

The theory can be traced to Taylor (1911), one of the earliest management writers who wrote: "It is impossible, through any long period of time, to get workmen to work much harder than the average man around them unless they are assured to a large and permanent increase in their pay".

\subsubsection{Content (Needs) Theory}

The content or needs theory is based on the fact that the content of motivation consists of needs (Armstrong, 2010). An unsatisfied need creates tension and a state of disequilibrium, and to restore the balance, a goal that will satisfy the need is identified wherein a behavior pathway that will lead to the achievement of the goal is selected (Armstrong, 2010).

According to the needs theory, not all needs are equally important for a person at any one time; some may provide a much more powerful drive towards a goal than others depending on the individual's background and present situation (Smith, 1994). 
The Needs theory was developed originally by Maslow who postulated the concept of hierarchy of needs (Shah \& Shah, 2010). Other theories associated with the needs theory is Herzberg's two- factor model, Alderfer's modified need hierarchy model and McClelland's achievement motivation model (Armstrong, 2010).

\subsubsection{Maslow Hierarchy of Needs}

Maslow's theory on the hierarchy of needs is one of the most popular theories of motivation and this forms one of the bases of the model for this study. A need is something that a person requires and satisfaction occurs when a need is fulfilled, and motivation is the attempt to satisfy a need (Aldag \& Kuzuhara, 2002).

Maslow (1954) identified that employees had five levels of needs and that human needs are in the form of a hierarchy ascending from the lowest to the highest. Maslow emphasise that no need can be fully gratified and that when a need is substantially satisfied, it ceases to be a motivator. This makes a person seeks a higher level of need (Drummond, 2000).

Maslow theorized that the lower level needs have to be satisfied before the next higher level need would motivate an employee (Armstrong, 2010). In Maslow's conclusion, in order to meet the needs of an employee, the employer had to understand the hierarchy of the need to which the employee belongs. According to Maslow (1954), listed from the lowest level of needs to the top are categorized as follows:

- Physiological needs: These are needs that focus on sustaining human life such as the need for oxygen, food, water and sex. Maslow stated that until these basic needs are satisfied to a large extent, no other motivating factor can operate (Armstrong, 2010).

- Security or Safety Needs: These are the next in hierarchy and focus on being free of physical danger and the fear of losing a job, property, food or shelter as well as protection against emotional disappointment.

- Social Needs: These are the needs that deal with the social aspect of man such as the need to belong and be accepted by others. It is the need for love, affection and acceptance as belonging to a group.

- Esteem needs: Maslow identified that as soon as people satisfy the need to belong and be accepted by others, the next higher level of need is the need to be held in high esteem by themselves and others. It goes on to state that these kinds of need produce satisfaction through power, prestige, status and self-confidence. It includes internal esteem factors such as self-respect, autonomy, achievements and external factors such as status, recognition and attention. 
- Self- Fulfilment (Self-actualization): This is the highest need in the hierarchy. It is the drive to become what one is capable of becoming, to maximize one's full potential and to accomplish something. It includes needs such as growth, achieving one's potential and self-fulfilment.

According to Maslow (1954), once a need has been satisfied, it no longer acts as a strong motivator and the need at the highest level becomes the "motivator". Maslow also sets out a distinction crucial for new employment-motivation theories (Smith, 1994).

For Maslow, as the higher- order needs for esteem and self fulfilment provide the greatest impetus to motivation, they grow in strength when they are satisfied, while the lower needs decline in strength on satisfaction (Warr, 1998). In relating Maslow's motive hierarchy to the work situation, Maslow identifies the esteem-need level as an important transition area for human incentive (Smith, 1994).

The need level constitutes a clear dividing point within the hierarchy with respect to the locus of the source of need fulfillment: for the lower half of the esteem stage and for those needs below, the accomplishment of need fulfillment is outside the person, through the manipulation of objects in the environment or through interpersonal contact (Armstrong, 2010). According to Aldag and Kuzuhara (2002), satisfaction occurs when needs are fulfilled which motivation attempt to satisfy.

In the gratification of self-esteem and self-actualization needs, the emphasis is on an internal reaction to events. Such sensations as the pleasure from successful achievement, the exercise of a personal skill, the acceptance of responsibility, are focused upon by Maslow (1954) as factors fulfilling the self-esteem and actualization needs.

This theory can be a useful tool in determining the kinds of rewards that could be effective in motivating employees. The key is to recognize every employee as an individual, and also for managers to remember that employees' needs differ from time to time (Butkus \& Green, 1999).

\subsubsection{Herzberg Two-Factor Theory}

The two-factor model of satisfiers and dissatisfiers was developed by Herzberg et al. (1959) following an investigation into the sources of job satisfaction and dissatisfaction of accountants and engineers. It was assumed that people have the capacity to report accurately the conditions that made them satisfied and dissatisfied with their jobs (Armstrong, 2010). 
Based on the two types of motivators, thus factors that result in satisfaction with one's job and those that result in dissatisfaction for employees at work, Herzberg (2003) stated that intrinsic factors are related to job satisfaction while extrinsic factors relate to dissatisfaction.

The theory was based on the question- What do people want from their jobs? (Harpaz, 1990). From the responses received, Herzberg concluded that removing dissatisfying characteristics from a job does not necessarily make the job satisfying (Armstrong, 2010). Herzberg identified the two major factors; motivators and hygiene factors that could lead to job satisfaction (Herzberg, 2003).

Herzberg noted that the motivators are intrinsic factors that permit psychological growth and development on the job such as achievement, recognition, responsibility, advancement, challenges and the work itself (Wilson, 2010; Ajila \& Abiola, 2004).

Hygiene factors on the other hand are extrinsic and describe the conditions of work rather than the work itself (Armstrong, 2010). These include job security, salary, work conditions, company policy, administration, supervision, interpersonal relations with subordinates and supervisors (Bhattacharyya, 2009). Herzberg (2003) concludes that employers should be concerned with the job itself and not only with the work conditions.

Chris and Awonusi (2004) argue that, extrinsic rewards have a significant impact on employee motivation while intrinsic rewards don't have any significant impact on employee motivation. Efficient reward system can be a good motivator but an inefficient reward system can lead to demotivation of the employees. Reio and Callahon (2004) conclude that both intrinsic and extrinsic rewards motivates the employee resulted in higher productivity.

\subsubsection{Process Theory}

The emphasis in process theory is on the psychological processes or forces that affect motivation, as well as basic needs (Armstrong, 2010). The process theory is also known as cognitive theory because it is concerned with people's perceptions of their working environment and the ways in which they interpret and understand it (Armstrong, 2010).

According to Armstrong (2010), process theory provides a much more relevant approach to motivation. Central to the process theory is a series of cognitive theories that attempt to understand the thought processes that people have when determining how to behave in the workplace (Steers \& Shapiro, 2004). One of the known cognitive theories is the expectancy theory presented by Victor Vroom as the first systematic formulation of the theory (Steers \& Shapiro, 2004). Following Vroom's expectancy theory are other process theories such as the goal achievement theory and equity theory. 


\subsubsection{Expectancy Theory}

In Spector (2000), expectancy theory explains how rewards lead to behavior by focusing on internal cognitive states that lead to motivation. According to Daft (2003, in Dartey-Baah, 2010), expectancy theory proposes that motivation depends on the individuals' expectations or outlook about their ability to perform tasks and receive desired rewards.

The theory was originally contained in the valency-instrumentality-expectancy (VIE) theory which was formulated by Vroom (1964, in Green, 2000). Valency stands for value; instrumentality is the belief that if one thing is done, it leads to another, and expectancy is the probability that action or effort will lead to an outcome (Vroom, 1964). The theory assumes that people think about what they are doing, what they are getting and its worth (Armstrong, 2010). Vroom's expectancy theory (Vroom, 1964) developed the topic of motivation combining the interaction of individual needs and employees working together.

The concept of expectancy theory was defined in more detail by Vroom (1964) as follows:

When an individual chooses between alternatives which involve uncertain outcomes, it seems clear that this behaviour is affected not only by his preferences among these outcomes but also by the degree of to which he believes these outcomes to be possible. Expectancy is defined as a momentary belief concerning the likelihood that a particular act will be followed by a particular outcome. Expectancies may be described in terms of their strength. Maximal strength is indicated by subjective certainty that the act will be followed by the outcome, while minimal (or zero) strength is indicated by subjective certainty that will not be followed by the outcome.

The strength of expectations may be based on past experiences (reinforcement), but individuals are frequently with new situations - a change in job, payment system, or working conditions imposed by management - where past experience is not an adequate guide to the implications of the change. In these circumstances, motivation may be reduced (Armstrong, 2010).

Motivation is only likely when a clearly perceived and usable relationship exists between performance and outcome, and the outcome is seen as a means of satisfying needs. This explains why extrinsic financial motivation - for example an incentive or bonus scheme works only if the link between effort and reward is clear [in the words of Lawler (2003) there is a "line of sight"] and the value of the reward is worth the effort. It also explains why intrinsic motivation arising from the work itself can be more powerful than extrinsic motivation. Intrinsic motivation outcomes are more under the control of individuals, who can place greater reliance on their past experiences to indicate the extent to which positive and advantageous results are likely to be obtained by their behaviour. 


\subsubsection{Goal Theory}

Goal theory was developed by Locke and Latham (1979) and it states that motivation and performance are higher when individuals have set specific goals, when goals are difficult but accepted, and when there is a feedback on performance. Participation in goal setting is important as a means of getting agreement to the setting of higher goals (Armstrong, 2010).

Erez and Zidon (1984) emphasized the need for acceptance of and commitment to goals. They found that as long as they are agreed, demanding goals lead to better performance than easy ones.

Locke, Smith, Erez, Chah and Shaffer (1994) point out that, goals inform individuals to achieve particular levels of performance, in order for them to direct and evaluate their actions, while performance feedback allows the individual to track how well he or she has been doing in relation to the goal so that adjustments in effort, direction or task strategies can be made.

\subsubsection{Equity Theory}

Equity theory recognises that individuals are concerned not only with the absolute amount of rewards they receive for their efforts, but also with the relationship of the amount to what others receive (Armstrong, 2010). Based on one's inputs, such as effort, experience, education and competence, one can compare outcomes such as levels, increases, recognition and other factors. When people perceive an imbalance in their outcome-input ratio relative to others, tension is created. The tension provides the basis for motivation, as people strive for what they perceive as equity and fairness (Robbins, 2005). One of the prominent theories with respect to equity theory was developed through the work of J.S. Adams. Adams' theory (Adams, 1963) is perhaps the most rigorously developed statement of how individuals evaluate social exchange relationships (Armstrong, 2010). The major components of exchange relationships in this theory are inputs and outcomes. In a situation where a person exchanges his or her services for pay, inputs may include previous work experience, education, effort on the job and training. Outcomes are those factors that result from the exchange. The most important outcome is likely to be pay with outcomes such as supervisory treatment, job assignments, fringe benefits and status symbols also taken into consideration.

Equity theory rests upon three main assumptions (Carrell \& Dittrich, 1978):

- The theory holds that people develop beliefs about what constitutes a fair and equitable return for their contributions to their jobs;

- The theory assumes that people tend to compare what they perceive to be the exchange they have with employers. 
- The theory assumes that when people believe that their own treatment is not equitable, relative to the exchange theory they perceive others to be making, they will be motivated to take actions they deem appropriate. This concept of equity is most often interpreted in work organisations as a positive association between an employee's effort or performance on the job and the pay the individual receives.

Adams (1965) suggested that individual expectations about equity or "fair" correlation between inputs and outputs are learned during the process of socialization and through the comparison with inputs and outcomes of others. To further establish the causes of perceived and actual inequity in organizations (Ramlall, 2004) stated that feelings of inequitable treatment tend to occur when people believe they are not receiving fair returns for their efforts and other contributions. As suggested by Adams (1965, in Armstrong, 2010), two forms of equity are also identified which are distributive and procedural equity. Distributive equity is concerned with individual's contribution and in comparison with others; and procedural equity or procedural justice is concerned with the perceptions employees have about the fairness with which procedures in such areas as performance appraisal, promotion and discipline are being operated.

Equity theory states, in effect, that people will be better motivated if they are treated equitably and de-motivated if they are treated inequitably (Armstrong, 2010).

\subsection{Job Satisfaction}

Job satisfaction has been defined in different ways and a definitive designation for the term is unlikely to materialise. Job satisfaction is a psychological concept that refers to job related attitudes and characteristics such as pay and reward, policies, leadership behaviours, management styles and co-workers (Dartey-Baah, 2010).

A general way to define it therefore is as an attitudinal variable which is defined below:

Job satisfaction is simply how people feel about their jobs and different aspects of their jobs. It is the extent to which people like (satisfaction) or dislike (dissatisfaction) their jobs (Spector, 2000).

Armstrong (2010) also draws the attention that job satisfaction refers to the attitudes and feelings people have about their work. This implies that positive and favourable attitudes towards the job indicate job satisfaction while negative and unfavourable attitudes towards the job indicate job dissatisfaction. According to Armstrong (2010), morale is often defined as being equivalent to job satisfaction. 
Armstrong (2010) defines morale as "the extent to which an individual's needs are satisfied and the extent to which the individual perceives that satisfaction as stemming from his total work situation". Gilmer (1961, in Armstrong, 2010) suggests that morale "is a feeling of being accepted by and belonging to a group of employees through adherence to common goals". Gilmer (1961) distinguishes between morale as a group variable related to the degree to which group members feel attracted to their group and desire to remain a member of it; and job attitude as an individual variable related to the feelings employees have about their job.

Job satisfaction is also defined by Cranny, Smith and Stone (1992) as an employee's affective reactions to a job based on comparing actual outcomes with desired outcomes. It is generally recognized as a multifaceted construct that includes employee feelings about a variety of both intrinsic and extrinsic job elements (Howard \& Frink, 1996).

An alternative approach is proposed by Sousa-Poza and Sousa-Poza (2000), based on the assumption that there are basic and universal human needs, and that, if an individual's needs are fulfilled in their current situation, then that individual will be happy. This framework postulates that job satisfaction depends on the balance between work-role inputs such as education, working time, effort and work-role outputs such as wages, fringe benefits, status, working conditions, intrinsic aspects of the job. If work-role outputs ("pleasures") increase relative to work-role inputs ("pains"), then job satisfaction will increase (Sousa-Poza \& Sousa-Poza, 2000).

Rose (2001) views job satisfaction as a bi-dimensional concept consisting of intrinsic and extrinsic satisfaction dimensions. Intrinsic sources of satisfaction depends on the individual characteristics of the person such as the ability to use initiative, relations with supervisors, or the work that the person actually performs which are symbolic or qualitative facets of the job. Extrinsic sources of satisfaction on the other hand are situational and depend on the environment such as pay, promotion, or job security; these are financial and other material rewards or advantages of a job.

As described by Rose (2001), the distinction relates to the double meaning of the word "job": the work tasks performed and the post occupied by the person performing those tasks. It is explained as: The meaning of "job" as a post or appointment is of primary importance. Every job is an instance of the employment relationship, embodying a contract (substantive or implied) to exchange an ability to work (labour, provide service, exercise ingenuity, direct efforts of others, etc.) for rewards (both material and symbolic). True, performing work tasks provides a stream of experiences, technical and social, that can energize psychosocially responses; any resulting data summarizing these reactions are indispensable. However, such data must not be weighted higher than those concerning experience of the overt (or ostensible) contractual terms - above all, those concerning pay and job security (Robbins, 2005) 


\subsubsection{The Relationship of Satisfaction and Dissatisfaction}

The most significant and basic difference between Herzberg's two factors is the inherent level of satisfaction/dissatisfaction within each factor. If motivation includes only those things which promote action over time, then motivators are the factors that promote long-running attitudes and satisfaction (Ramlall, 2004).

According to Herzberg et al. (1959), motivators cause positive job attitudes because they satisfy the worker's need for self-actualization (Maslow, 1954), the individual's ultimate goal. The presence of these motivators has the potential to create great job satisfaction; however, in the absence of motivators, Herzberg says, dissatisfaction does not occur. Sometimes management pays more attention to extrinsic rewards but intrinsic rewards are equally important in employee motivation (Andrew \& Kent, 2007). Intangible or psychological rewards like appreciation and recognition plays a vital role in motivating employee and increasing his performance. Andrew and Kent (2007) conclude that commitment of employees is based on rewards and recognition.

Likewise, hygiene factors, which simply "move" (cause temporary action), have the potential to cause great dissatisfaction. Similarly, their absence does not provoke a high level of satisfaction.

Job satisfaction contains two separate and independent dimensions (House \& Wigdor, 1967). These dimensions are not on differing ends of one continuum but instead they consist of two separate and distinct continua.

According to Herzberg (2003), the opposite of job satisfaction is not dissatisfaction, but rather a simple lack of satisfaction. In the same way, the opposite of job dissatisfaction is not satisfaction, but rather "no dissatisfaction". For example, consider the hygiene factor, work conditions; if the air conditioner breaks in the middle of a hot summer day, workers will be greatly dissatisfied. However, if the air-conditioner works throughout the day as expected, the workers will not be particularly satisfied by taking notice and being grateful (Ramlall, 2004).

\subsubsection{Factors affecting Job Satisfaction}

The level of job satisfaction is affected by intrinsic and extrinsic motivating factors, the quality of supervision, social relationships with the work group and the degree to which individuals succeed or fail in their work (Wilson, 2010). Wilson (2010) believe that discretionary behaviour which helps the firm to be successful is most likely to happen when employees are well motivated and feel committed to the organisation and when the job gives them high levels of satisfaction. The research findings were that the key factors affecting job satisfaction were 
personal expectations, career opportunities, job influence, team and job challenge (Wilson, 2010).

\subsubsection{Personal Expectations}

According to Tang, Chiu and Luk (2002), different expectations that men and women bring to the workplace provide a third possible explanation for women's greater reported job satisfaction. Complaints about work result not just from objective problems at work, but also from the expectations brought to the work situation. Tietjen and Myers (1998) posits that, because of extensive occupational segregation, female workers may have little occasion to compare their jobs with that of their male counterparts contributing to their relative job satisfaction. In effect, they may not have full information on, or at least daily reminders of, the extent to which they are under-rewarded. Thus, women who are in jobs with a high concentration of women may not make the sort of comparisons that would lead them to be dissatisfied with their jobs.

In the ILO convention, work - formal and informal, paid and unpaid, plays a central role in the lives of people all across the world. Through work, women and men define themselves and their roles in society. Yet, while many jobs provide both income and personal satisfaction, they may also pose hazards and risks to health and safety. The ILO estimates that each year about 2.3 million men and women die from work-related accidents and diseases, including close to 360,000 fatal accidents and an estimated 1.95 million fatal work-related diseases. Hazardous substances cause an estimated 651,000 deaths, mostly in the developing world. These numbers may be greatly underestimated due to the inadequate reporting and notification systems in many countries.

The risks to men workers are better known given that occupational safety and health considerations had previously focused on dangerous jobs, in sectors dominated by male workers. However, women represent over 40 percent of the global workforce, or 1.2 billion out of the global total of 3 billion workers (ILO, Global Employment Trends for Women, March 2009). The increasing proportion of women in the workforce has lead to a range of genderrelated questions about the different effects of work-related risks on men and women, in terms of exposure to hazardous substances, or the impact of biological agents on reproductive health, the physical demands of heavy work, the ergonomic design of workplaces and the length of the working day, especially when domestic duties also have to be taken into account.

According to the (ILO, Global Employment Trends for Women in March, 2009), occupational health and safety (OHS) hazards affecting women workers have been traditionally under-estimated because OHS standards and exposure limits to hazardous substances are based on male populations and laboratory tests. 
Sex-based labour force segregation contributes to different workplace health and safety challenges for women and men. Men are more present in industries such as construction and mining, while the vast majority of women workers are in agriculture and the services sectors (Forastieri, 2000). Women are more likely than men to have low paid jobs and are less likely than men to be supervisors and managers. A significant proportion of women can also be found in the informal economy where they face unsafe and unhealthy working conditions, low or irregular incomes, job insecurity and lack of access to information, markets, finance, training and technology.

\subsubsection{Motivation and Job Satisfaction}

The relationship between an employee's motivation and job satisfaction is examined. A number of researchers (Heneman, Greenberger \& Strasser, 1988; Igalens \& Roussel, 1999; Pool, 1997) have concluded that work motivation and job satisfaction should be treated separately, so that factors of influence can be more readily identified and to allow for better understanding.

Herzberg's (2003) motivation-hygiene theory identifies intrinsic motivators (e.g., achievement, recognition, the work itself) and hygiene factors which tend to be extrinsic factors (e.g., company administration, supervision, salary). Herzberg's view is that these motivators lead to job satisfaction because they satisfy an individual's need for self-actualisation (Maslow, 1954; Tietjen \& Myers, 1998).

Expectancy theory, as developed by Porter and Lawler (1968), argues that a pay-for-performance system influences job satisfaction (Ferris, 1977; Igalens \& Roussel, 1999). Supporting this view, Pool (1997) examines the relationship between work motivation and job satisfaction and finds significant positive association indicators that, as work motivation increases, job satisfaction increases. In relation to extrinsic motivation, a positive association with job satisfaction has also been found (Moynihan \& Pandey, 2007; Wright \& Kim, 2004). While the dominant argument has been for a positive association between extrinsic motivation and job satisfaction, Frey (1997) argues for a "crowding-in" effect.

Intrinsic motivation can increase as a result of work enhancement programmes that have increased work morale (Frey, 1997). When employees' enjoyment of their job increases, intrinsic rewards may undermine the extrinsic motivation (Frey, 1997). The proponents of selfdetermination theory argue that pay can have a positive effect on intrinsic motivation by being supportive and encouraging employee autonomy and self-esteem (Deci \& Ryan, 2008; Gagne \& Deci, 2005).

However, self-determination theory remains silent on whether extrinsic motivation will decrease, if intrinsic motivation increases. But the findings of the studies of self-determination 
theory suggest that supportive work environments, which encourage intrinsic motivation, will result in increased job satisfaction and more effective performance (Gagne \& Deci, 2005; Deci \& Ryan, 2008; Kunz \& Pfaff, 2002). When pay systems link individual and organizational performance, employees can see how important their work is, which in turn increases their job satisfaction because they are able to fulfill high-order needs, such as self-esteem (Wright \& Kim 2004).

\subsubsection{Socio-demographical Factors as Determinants of Job Satisfaction}

Determinants of job satisfaction often applied in analyses performed within labour economic theory include education, job tenure, managerial position, the unemployment rate, and marital status (Ghinetti, 2007). Tenure and having a leading position have nearly always been found to be positively related to job satisfaction (Clark, 1997). The relationships between job satisfaction, level of education, the unemployment rate, and wages are intertwined and convoluted (Bryan \& Sell, 2011).

Education raises wages and thus job satisfaction. It also raises expectations with respect to job content and thus the likelihood of experiencing job dissatisfaction (Bryan \& Sell, 2011). Many studies have also shown that higher educated workers are less satisfied than lower educated workers (Blanchflower \& Oswald, 1999). The common interpretation of this is that, job satisfaction depends on the gap between outcomes and aspirations, and that aspirations are increased by education. In considering a unique level of education, this type of difficulty is eliminated. Senge (1992) confirms in his studies that the better trained, educated and motivated the workforce, the more likely it is that an organisation will be successful.

The homogeneity of the group that results from the study of a unique level of education may reveal other mechanisms that are not visible when considering different levels of education (Clark, 2001).

Many of the earlier studies on job satisfaction have made an analytical distinction between males and females as there has been reported higher job satisfaction for women (Sloane \& Williams, 2000; Clark, 1997). Whereas Sloane \& Williams (2000) find that the differences stem from men and women having different types of work, Clark (1997) finds that neither different jobs; their different work values; nor sample selection accounts for the gender satisfaction differential. Rather Clark (1997) proposes an explanation based on well-being relative to expectations.

A man and a woman with the same jobs and levels of expectations would report identical levels of job satisfaction. But as women's expectations are lower than men's due to having been 
more attached to work in the home, they will report higher job satisfaction than their male counterparts even given the same working conditions (Clark, 1997).

According to Ashwathapa (2005), individuals experience different degree of motivation at different stages of their life. Indicating that motivation is high at the initial stage, gets gradually reduced, starts rising up to certain stage, and finally dips to a low degree. The possible reasons for this phenomenon are like this. When individuals join an organization, they may have some unrealistic assumptions about what they are going to drive from their work. These assumptions make them more satisfied. However, when these assumptions fall short of reality, job satisfaction goes down. It starts rising again as the people start to assess the jobs in right perspective and correct their assumptions. At the last, particularly at the far end of the career, job satisfaction goes down because of fear of retirement and future outcome.

\subsubsection{Dimensions of Job Satisfaction Impacting on Motivation}

An important factor in relation to job satisfaction is wage (Bryan \& Sell, 2011). The general assumption is that higher wage increases job satisfaction, not necessarily because it actually makes you happier in the job, but because a higher wage increases overall utility by increasing total expenditure opportunities (Bryan \& Sell, 2011). Wage is used as one type of reward along with recognition and future opportunities at the job (Clark \& Oswald, 1996).

Employees are sometimes motivated by promotional opportunities or responsibility enlargement. Nabi (2000) stated that "Career-orientated motivation in terms of advancement motivation (i.e. ambition about career progression) and work importance (i.e. the salience or centrality of work and career compared with other areas of life satisfaction)". This means a person who is career-oriented has a strong sense of professional growth, or obtains high satisfaction levels or happiness from the job.

Filipkowski and Johnson (2008) examined the relationships between measures of job insecurity, organizational commitment, turnover, absenteeism, and worker performance within a manufacturer. A positive relationship was found between job insecurity and intentions to turnover, and a small negative correlation was found between measures of job insecurity and organizational commitment.

Benabou and Tirole (2006) apply a general job satisfaction measure, which makes it difficult to distinguish the two effects. Not only absolute, but also relative wage is considered to be positively correlated to the level of job satisfaction. This is when using the wages of other workers having the same characteristics and type of job for comparison (Clark \& Oswald, 1996). 
The level of job satisfaction may be influenced by ability thus representing unobservable, stable characteristics of individuals (Demoussis \& Giannakopoulos, 2007).

Schneider and Dachler (1978) have shown that the level of job satisfaction varies very little over time, suggesting that it does reflect underlying stable personal dispositions. This has been tested on a cohort of German employees by Dormann and Zapf (2001) in a review on the studies on the alleged stability of job satisfaction. The result suggested that after controlling for stable working conditions, the stability of job satisfaction diminishes to non significance, indicating that an underlying dispositional influence on job satisfaction is not direct, but mediated by working conditions. This also suggests that the level of job satisfaction can be changed by organizational measures.

Ren (2010) points to the value congruence that organization and employees can strengthen the intrinsic motivation and satisfaction. Ren (2010) also investigates whether value congruence can impact the design of the organization and finds that, value congruence is related to employee participation in decision making and autonomy as opposed to control which affect job satisfaction.

\subsubsection{Job Satisfaction and Performance}

For decades, organizational researchers have been intrigued by employee satisfaction with work. Some studies have examined antecedents of job satisfaction, specific dimensions of job satisfaction, and the relationship between job satisfaction and outcomes such as job performance (Igalens \& Roussel, 1999; Pool, 1997).

Among many individual antecedents that influence employees' innovative performance are attitudes (Williams, 2004), cognitive styles (Scott \& Bruce, 1994), personality and demographic characteristics such as age, education background, and prior R\&D experience (Roberts, 1991; Rothwell, 1992). In terms of organizational antecedents, expenditure on Research \& Development (Hadjimanolis, 2000), cooperation with external technology provider, leader's influence (Hage \& Dewar, 1973), and reward system (Eisenberger \& Cameron, 1996; Janssen, 2000; Mumford, 2000) are commonly cited as factors that affect individuals' innovative performance.

Kahya (2007) also investigated on certain factors that affect the job performance. Some studies were reviewed describing the effect of experience, salary, education, working conditions and job satisfaction on performance. As a result of the research, it has been found that several factors affected the employee's performance. The position or grade of an employee in a company was of high positive effect on his or her performance. Working conditions and environment, on the other hand, had shown both positive and negative 
relationship on performance. Highly educated and qualified employees showed dissatisfaction of bad working conditions and thus affected their performance negatively. Employees of low qualifications, on the other hand, showed high performance in spite of the bad conditions. In addition, experience showed positive relationship in most cases, while education did not yield clear relationship with the performance (Kahya, 2007).

Meta-analyses have shown that the relationship between performance and job satisfaction is positive, but small (George \& Jones, 1997). However, analysis at the organisational level has shown that organisations with higher average levels of job satisfaction outperform other organisations (Ostroff, 1992). Some studies have suggested there is still lack of workable understanding of the way different factors such as work values, job satisfaction, and performance interact with one another (George \& Jones, 1997).

Porter and Steers (1973, in Pool, 1997) argued that the extent of employee job satisfaction reflected the cumulative level of met worker expectations. This means that employees expect their job to provide a mix of features (e.g. pay, promotion, autonomy) for which the employee has certain preferential values. The range and importance of these preferences vary across individuals, but when the accumulation of unmet expectation becomes sufficiently large there is less job satisfaction, and greater probability of withdrawal behaviour (Pearson, 1991).

According to Wheelan (2010), education chances - organizations that focus on educating and training people about the technical aspects of their jobs and about effective group participation will increase the likelihood that organizational groups will become high performance teams.

Job satisfaction is focused primarily on its impact on employee commitment, absenteeism, intentions to quit, and actual turnover (Agho, Mueller \& Price, 1993). However, across studies, the proportion of variance in turnover explained by levels of satisfaction may be smaller than originally thought (Hom \& Griffeth, 1991; Lee, Law \& Bobko, 1999).

On the other hand, a two-year longitudinal study showed that employees who changed jobs and stayed in the same occupation and employees who did not change jobs at all (Wright \& Bonnett, 1992). In particular, satisfaction with the facets of meaningful work and promotion opportunities were significant predictors of intentions to leave an organization.

Mathieu (1991) tests of the causal ordering of job satisfaction and organizational commitment found that the effects of a variety of antecedents on organizational commitment were mediated by their impact on the job satisfaction (Tsui, Egan \& O 'Reilly, 1992).

Aspects of the work situation have been shown to be determinants of job satisfaction (Arvey, Carter \& Buerkley, 1991). For example, a broad situational factor, job level, is positively correlated with satisfaction with all aspects of the job probably because higher- level jobs tend to have better working life. 


\subsection{Mining in Ghana}

Ghana's mining tradition, particularly regarding gold dates back to the fifteenth century (Irvine, 1991). The historical importance of mining in the economic development of Ghana is considerable and well documented, with the country's colonial name "Gold Coast" reflecting the importance of the mining sector (The World Bank, 1992). Gold dominates the mining sector and by 2009, Ghana was the second-ranked African producer after South Africa, and had become the world's ninth largest producer of gold, at some $3.8 \%$ of global production, up from $2.6 \%$ five years earlier (Hilson, 2004).

Gold has been produced for over 1,000 years in the territory of the Ancient Kingdom of Ghana, the Gold Coast Colony and post-independence Ghana (Hilson, 2004). As with South Africa, which Ghana currently follows as the second-ranked African producer, large-scale industrial gold mining in Ghana dates back to the last quarter of the 19th Century.

From the inception of Ghana's economic policy changes in 1983, the mining sector has witnessed a considerable investment boom and increased production, particularly in the gold and bauxite sector (Coakley, 1999). There has been considerable growth in the number of new mines and exploration companies.

Ghana's mining tradition, particularly regarding gold, dates back to the fifteenth century, but has since had a rather ragged history. British and a few other foreign investors controlled the industry during the colonial period (Coakley, 1999). Developments in the mining industry at this stage were responses to economic and political developments in Britain and Europe in general rather than to market conditions. The industry was very vibrant during the preindependence period. Ghana accounted for $36 \%$ of total world gold output $(8,153,426$ fine ounces) between 1493 and 1600, but its share of world mineral output dwindled over subsequent years.

The post-independence period was marked by state ownership of mineral resources. The period up to 1986 was generally characterised by stagnation of the industry, except for a few spikes recorded immediately after independence and in the early 1970s. The sluggish production, particularly in the gold sector, could be attributed to market conditions, investor uncertainty about the safety of their investment under Ghanaian self-rule and the effects of state intervention in the industry.

As part of Ghana's economic recovery programme (ERP) launched in 1983, the mining sector underwent significant reforms beginning in 1986 (Nyanteng, 1997). This section looks at the dynamics and performance of the mineral industry in Ghana from the colonial era exploring the local and global factors responsible for the evolution of the industry throughout the period. 


\subsubsection{Pre-Independence Period}

Large-scale mining by British and other foreign investors began in the late 19th century. In pre-colonial times, present-day Ghana was one source of the gold that reached Europe via trans-Saharan trade routes (Irvine, 1991).

In the fifteenth century, Portuguese sailors tried to locate and to control gold mining from the coast but soon turned to more easily obtained slaves for the Atlantic slave trade. Most gold mining before the mid-nineteenth century was alluvial, miners recovering the gold from streams (Coakley, 1999).

Modern gold mining that plumbs the rich ore deposits below the Earth's surface began about 1860, when European concessionaires imported heavy machinery and began working in the western areas of present-day Ghana. The richest deposit, the Obuasi mine, was discovered by a group of Europeans who sold their rights to E.A. Cade, the founder of Ashanti Goldfields Corporation (AGC).

British mining interests were a significant source of influence on the Colonial Office in London and its representatives in the territory and shaped the formulation and implementation of mineral policy in the colony.

The thrust of policy in the sector was aimed, first at establishing a legal and administrative framework that would facilitate mining operations and secondly, ensuring the self-sufficiency of the British Empire (Tsikata, 1997). For instance, the development of minerals such as bauxite and manganese in Ghana was a function of the needs of Britain and carried out with the active participation of British state. Although a concession for mining bauxite in the Awaso area was obtained in 1926, production only started in 1940-41. This was when other sources of bauxite were cut off the Allied forces in the early part of World War II.

British Aluminium Company Limited, acting as agents for the British Ministry of Aircraft Production, started exploitation of the Ayawaso deposit. Similarly, exploitation of manganese in Ghana started in 1916 at the request of the Wartime Ministry of Munitions, as manganese was in high demand for war purposes.

The period from 1480 to 1954 was characterized by two major periods of peak production referred to as the "Jungle booms" and three periods of depressed production, attributed to various reasons including the influence of the two World Wars. Ghana accounted for $36 \%$ of total world gold output $(8,153,424$ fine ounces) between 1493 and 1600 , but this share dwindled over the years as a result of new producers. Total production up to 1934 was about 30 million fine ounces of gold representing $2.7 \%$ of worldwide production (Coakley, 1999).

The First and Second World War periods were characterised by low production. Rapid closure of small and medium mines that were starved of supplies because of the war affected output. In 
addition, the drafting of men and miners who could handle explosives to the warfront and the internment of German concessionaires by the British were some of the reasons accounting for the low production during the period. The depressed gold production in 1918-1929 was attributed to labour scarcity. The booming cocoa and construction industries and the emergence of the manganese and diamond mines affected the labour supply. But the growing number of Ghanaians who preferred to work their small mines also affected the labour availability.

In fact the preference of Ghanaians to work in their own mines rather than work for the Europeans encouraged the Colonial Office to pass the Mercury Ordinance of 1932, making it illegal for Ghanaians to use mercury for mining. This marked the beginning of the criminalisation of indigenous, small-scale gold mining and the edging out of Ghanaian gold producers, until 1989 when the Small-scale Mining Law was enacted to give legal status to the sector again.

The banning of indigenous gold mining did boost large-scale mining as more labour was freed for the latter and the period 1933 to 1942 saw increased mine output. The emergence of major new producing countries and the growing struggle for independence creating political risk and investor disquiet were responsible for the territory's dwindling share of world production from 1943 to 1954 . State intervention immediately after independence was to ensure that mines with considerable labour force threatening closure did not do so for obvious reasons. Since the beginning of the twentieth century, modern mining in the Gold Coast has been pursued as a large-scale venture, necessitating significant capital investment from European investors (Coakley, 1999).

\section{Research Methodology}

\subsection{Research Paradigm}

The study adopted both qualitative and quantitative method (mixed method). According to Malhotra (2007: page 42), qualitative research is exploratory in nature, based on small samples, and may utilize popular qualitative techniques such as focus groups (group interviews), word association (asking respondents to indicate their first responses to stimulus words), and in-depth interviews (one-on-one interviews that probe the respondents' thoughts in detail). Using qualitative and quantitative method reduces the weakness and improves the quality of the study (Malhotra, 2007). By triangulating the qualitative data, it was used to determine the outcome of the research. 


\subsection{Research Design}

The study employed a descriptive and exploratory research design in a comparative analysis of employee motivation and work performance among mining companies in Ghana. Zikmund (2003) explains descriptive research as the process of transforming raw data into understandable information so that it is easier to interpret. Exploratory research is conducted into an issue where there are a few studies to refer to (Marshall \& Rossman, 1995). The researcher therefore explores the relationships and differences about employee motivation within the various gold mining companies to provide significant insight into the study.

\subsection{Source of Data}

The study dwells on primary source of data because it provides empirical information for the study. Structured questionnaires and face to face interviews were conducted to gather information from participants. The questions which were contained in the questionnaire were closed and open-ended. The open-ended questions gave respondents the chance of providing additional information. The questionnaire was divided into four sections. Section A sought information about the biographical data of respondents such as age, gender, marital status, qualification, tenure and the department in which they work.

Section B and C sought employees' understanding and experience of motivation specifically intrinsic and extrinsic work motivation and job satisfaction respectively; and the last section also sought information relating to work performance. E.g. 1: What is your understanding of motivation? 2. Please rank the following intrinsic and extrinsic factors of motivation as per your priority on a scale 1-5 by indicating 1, 2, 3, 4, or 5 where 1=Very good, 2=Good, $3=$ Satisfactory, $4=$ Fairly good, $5=$ Not good.

\begin{tabular}{|l|l|l|l|}
\hline \multicolumn{1}{|c|}{ Intrinsic Factors } & \multicolumn{1}{c|}{ Scale } & \multicolumn{1}{c|}{ Extrinsic Factors } & Scale \\
\hline a. Recognition & & a. Company policy & \\
\hline b. Achievement & & b. Good work environment & \\
\hline c. Responsibility & & c. Good wages & \\
\hline d. Opportunity for Growth & & d. Challenge in job & \\
\hline
\end{tabular}

Table 1. Intrinsic and Extrinsic Factors of motivation

The questions were meant to be answered by all employees including managers and nonmanagers. This was with the aim of comparing employee motivation and work performance among the selected mining companies in Ghana. 
The questionnaire was used to explore the effectiveness of motivational tools and strategies used by the mining companies. Likert- type scale of questions were set where the respondents were asked to rate the level of their agreements towards a given statement. Examples of such type of questions are given as: Please indicate by ticking 1, 2, 3, 4 or 5 to respond to the statements what extents you agree or disagree with each. (1=Strongly agree, 2=Agree $3=$ Neutral, 4=Disagree, 5=Strongly disagree), The great sense of personal satisfaction I receive on my job enables me to perform well.

A structured interview schedule was designed for only the human resources managers and the union executives. The HR Managers represent the entire management and they have the major responsibility of motivating the employees hence, their opinion could not be ignored. The union representatives were also interviewed because they represent the employees in negotiations, it was worth they share their opinion on employee motivation and work performance on behalf of their members (employees). The interview was a scheduled one with each manager and union representative at their own convenience and lasted for an average of fifteen minutes. The interview schedule was designed to allow each respondent an unrestricted answer in his own words. The main focus was to acquire several supplementary data through a more comprehensive means. The questions on the interview schedule were also designed to broaden and reinforce those of the quantitative survey questionnaire and consequently focused on the hypotheses of the study.

\subsection{Choice of Organization}

Participating organizations included Goldfields Ghana Ltd. (Tarkwa Mines), AngloGold Ashanti Ltd. (Obuasi Mines), Chirano Gold Mines Ltd. and Newmont Ghana Ltd. (Ahafo) Mines, and the participants were junior and senior staff of the selected organizations.

First of all, the mining industry was selected because it is a hybrid sector whereby the government and private individuals have a share or stake in its operations and the researcher felt that a study on employee motivation within such sector would be best justified. Secondly, the jobs within the mining industry are normally associated with high responsibility, as employees have to go underground to perform duties which is quite challenging, considering the risk factors associated with it. Therefore having motivated employees could really be of importance to the industry and it was chosen.

Gold mining companies were specifically chosen for the study because the management of these selected companies expressed interest and a high need for research on the topic. Also, these selected companies are part of the large scale major mines in Ghana (Hilson, 2004). Since the staff of the industry are guided by rules of the National Environmental Policy, Minerals Commission and Ghana Chamber of Mines and their working conditions are similar to 
those of other mining industries, it was essential to compare employee motivation and its impact on performance in this sector. Table 2 below presents the major mines in Ghana together with their mine owner(s)/nationality and production in $(\mathrm{kg})$.

\begin{tabular}{|c|c|c|}
\hline Mine & Mine Owner(s) and Nationality & Production in 2010 (kg) \\
\hline Tarkwa & Gold Fields (SA) and IAMGOLD (Canada) & 20,432 \\
\hline Ahafo & Newmont Mining (USA) & 15,450 \\
\hline Obuasi & AngloGold Ashanti (SA/Ghana) & 8,987 \\
\hline Chirano & Red Back Mining now Kinross (Canada) & $5,188^{\S}$ \\
\hline
\end{tabular}

${ }^{\text {s}}$ The production quantity for 2009 .

Table 2. Selected Large Scale Mines in Ghana

\subsection{Sampling Technique and Sample Size}

Both probability and non-probability sampling method was adopted. The non-probability sampling method was convenient sampling. According to Mohammad, Habib and Zakaria (2010), the use of convenience sampling in selecting study participants was a better alternative since it allows for the theoretical generalisations of the findings. A convenience sample was used, as it was conveniently accessible through the permission granted by the management of the mining companies, and not specifically designed or structured for the study.

The probability sampling was stratified sampling. The basis of the stratification involved six departments within the mining companies dichotomized into technical and administration.

Sample of 248 employees were targeted from the entire population (workforce) from the mining companies. The study focused on employees at all levels of the organization. Four (4) managerial staff and four (4) union representatives were interviewed. Of the two hundred and forty-four (248) employees targeted, 240 structured questionnaires consisting of 34 questions were distributed to the four mining companies. However, two hundred (200) completed questionnaires were returned representing approximately 83 percent response rate. According to Punch (2003), a low response rate can raise questions according to whether the responses received were representative of the sample. A researcher should therefore strive for at least 60 percent response rate according to Punch (2003). The 83 percent response rate in this research was therefore taken to be acceptable. Sixty (60) questionnaires were distributed to each company. Table 3 below presents the number of questionnaires administered and retrieved from the various companies. 


\begin{tabular}{|c|c|c|}
\hline Name of Organization & $\begin{array}{c}\text { Number of Questionnaires } \\
\text { Administered }\end{array}$ & $\begin{array}{c}\text { Number of Questionnaires } \\
\text { Retrieved }\end{array}$ \\
\hline AngloGold Ashanti Ltd. & 60 & 57 \\
\hline Newmont Ghana Ltd. & 60 & 42 \\
\hline Goldfields Ghana Ltd. & 60 & 53 \\
\hline Chirano Gold Mines Ltd. & 60 & 48 \\
\hline Total & $\mathbf{2 4 0}$ & $\mathbf{2 0 0}$ \\
\hline
\end{tabular}

Table 3. Distribution of Name of Organization, Number of questionnaires administered and number of questionnaires retrieved

Employees responded to the questionnaire from their respective departments including the technical department (engineering, processing and mining) and non technical department or administration (EH\&S, Accounts and HR).

\subsection{Data Gathering Procedure}

The researcher obtained permission from the Human Resources Managers of the companies involved in the study to conduct the research in their companies, and permission was granted. A synopsis was attached to the questionnaire and interviews scheduled inviting them to participate. In each organization, one of the managers acted as a liaison for the researcher and enabled access to the technical and the non technical (administration) departments. The synopsis explained the purpose of the research, and that participation was voluntary and information obtained was going to be used for academic work only. The format of the questionnaire was also outlined.

\subsection{Mode and Instruments for Data Analyses}

The Statistical Package for Social Sciences (SPSS) was used for the analyses of all the data that was received. Descriptive statistics was used to run the basic statistical measures such as the mean, median, and standard deviation. The mean is a measure of central tendency which provides an arithmetic average for the distribution of scores (Coolican, 1999). Inferential statistics were used to test for the hypotheses. Inferential tests are used to infer whether differences or relationships between samples of data are significant, or whether they reflect real effect in populations (Coolican, 1999).

One-way analysis of variance (ANOVA) and independent T-test were used to determine significant differences between the demographic characteristics selected for the study. The results were discussed against the theoretical literatures pertaining to the constructs around 
which the study revolved, and were referenced to the literature in each case. The inferences made followed an inductive reasoning approach, since the generalizations made stemmed from data extracted from the sample.

\section{Data Analysis and Interpretation of Results}

A stratified random sampling was used to select 240 respondents from four mining companies and structured questionnaire consisting of 34 questions grouped into four sections given to each respondent. However, 200 completed questionnaires were retrieved representing approximately 83 percents response rate. The questionnaire included demographic information which assessed respondents' age, gender, educational background and name of company. Table 4 below shows the demographic results.

\begin{tabular}{|c|c|c|c|}
\hline & Item & Frequency & Percentage \\
\hline \multirow{2}{*}{ Gender } & Male & 145 & 72.5 \\
\hline & Female & 55 & 27.5 \\
\hline \multirow{2}{*}{ Age } & $20-40$ years & 137 & 68.5 \\
\hline & $41-60$ years & 63 & 31.5 \\
\hline \multirow{4}{*}{ Name of Company } & AngloGold Ashanti Ltd & 57 & 28.5 \\
\hline & Goldfields Ghana Ltd & 53 & 26.5 \\
\hline & Chirano Gold Mines Ltd & 48 & 24.0 \\
\hline & Newmont Ghana Ltd & 42 & 21.0 \\
\hline \multirow{5}{*}{$\begin{array}{l}\text { Educational } \\
\text { Background }\end{array}$} & A/O Level & 13 & 6.5 \\
\hline & SSSCE and below & 21 & 10.5 \\
\hline & Diploma & 63 & 31.5 \\
\hline & First Degree & 86 & 43.0 \\
\hline & Masters/PhD & 17 & 8.5 \\
\hline
\end{tabular}

Table 4. Demographic Characteristics

Table 4 above shows gender distribution of respondents. From the table, it is revealed that majority of the respondents' were males, about 73 percent representing a bigger part of the sample group. However, about 27 percent were females.

With regards to the age distribution of the respondents as presented in Table 4 above, majority are falling in the age group of 20-40 years representing about 69 percent followed by age group 41-60 years also representing about 32 percent.

As indicated earlier in this chapter, respondents for the study were selected from four large-scale mining companies. A stratified random sample with equal allocation of 60 respondents each from the four companies was used. The breakdown is as follows; Anglo Gold 
Ashanti Limited 57 respondents representing 28.5 percent, Newmont Ghana Limited 42 respondents representing 21 percent, Goldfields Ghana Limited 26.5 percent, and Chirano Gold mines Limited 48 respondents representing 24 percent.

For the educational background of the respondents as shown in Table 4 above, about 6.5 percent had $\mathrm{A} / \mathrm{O}$ Level qualification, 11 percent had SSSCE qualification, 32 percent had Diploma in various field while 43 percent representing the majority of the respondents also had first degree in various fields of study. However, 9 percent of the respondents had Masters' degree or PhD.

\subsection{Reliability Test}

The internal consistency of the questions measuring job satisfaction, intrinsic and extrinsic factors that drive motivation, level of motivation and work performance were tested using the cronbach's test and presented in Table 5 below. An alpha of 0.7 and above is considered desirable by social scientist and clearly from the results in Table 5 below, Cronbach's alpha for job satisfaction 0.876 , extrinsic factors 0.764 , intrinsic factors 0.71 , level of motivation and work performance, 0.87 and 0.836 respectively. These indicate that all scales had internal consistency and were therefore reliable for use.

\begin{tabular}{|l|r|r|}
\cline { 2 - 3 } \multicolumn{1}{c|}{} & Cronbach's Alpha & No. of Items \\
\hline Satisfaction & 0.876 & 15 \\
\hline Extrinsic Factors & 0.764 & 4 \\
\hline Intrinsic Factors & 0.71 & 4 \\
\hline Motivation & 0.87 & 8 \\
\hline Work Performance & 0.836 & 9 \\
\hline
\end{tabular}

Table 5. Reliability Test 


\subsection{Hypotheses Testing}

\subsubsection{Intrinsic Motivation and Work Performance}

$\mathbf{H}_{\mathbf{1}}$ : There is a significant relationship between Intrinsic Motivation and Work Performance

\begin{tabular}{|l|r|r|l|}
\cline { 2 - 4 } \multicolumn{1}{c|}{} & \multicolumn{3}{c|}{ Intrinsic Motivation } \\
\cline { 2 - 4 } \multicolumn{1}{c|}{} & \multicolumn{1}{c|}{ Mean } & P-value & \multicolumn{1}{c|}{ F } \\
\hline A/O' Level & 8.6923 & 0.000 & 5.846 \\
\hline SSSCE and below & 8.2857 & & \\
\hline Diploma & 10.0159 & & \\
\hline First Degree & 7.5349 & & \\
\hline Masters/PHD & 9.1765 & & \\
\hline
\end{tabular}

Table 6. Intrinsic motivation across Educational Levels

[One-Way Analysis of Variance (ANOVA)]

One-way analysis of variance (ANOVA) was employed to test if there exist, a significant differences in scores on intrinsic motivation in the mining sector, across levels of education of the respondents to determine its impact on performance as shown in Table 6 above. Scores on intrinsic motivation was significantly different across levels of education of the respondents, $F(4,200)=5.846, p<0.05$.

The null hypothesis was rejected that no difference exists in intrinsic motivation from the mining companies sampled and can be concluded that there were significant differences observed in scores on intrinsic motivation with respect to educational levels of the respondents.

With this observation the researcher went further to find out where the differences exist by using the average scores on intrinsic motivation. From Table 6 above, the group with the highest score on intrinsic motivation were First degree holders followed by SSSCE and below; next was A/O level and with Masters or PhD, while the least group were those with diploma. 


\subsubsection{Extrinsic Motivation and Work Performance}

$\mathbf{H}_{\mathbf{2}}$ : There is a significant relationship between Extrinsic Motivation and Work Performance.

\begin{tabular}{|l|r|r|l|}
\cline { 2 - 4 } \multicolumn{1}{c|}{} & \multicolumn{3}{c|}{ Extrinsic Motivation } \\
\cline { 2 - 4 } \multicolumn{1}{c|}{} & Mean & P-value & \multicolumn{1}{c|}{ F } \\
\hline A/O' Level & 10.00 & 0.280 & 2.788 \\
\hline SSSCE and below & 9.62 & & \\
\hline Diploma & 10.67 & & \\
\hline First Degree & 9.06 & & \\
\hline Master/PhD & 11.00 & & \\
\hline
\end{tabular}

Table 7. Extrinsic motivation across Educational Level

[One-Way Analysis of Variance (ANOVA)]

From Table 7 above, analysis of variance conducted was to find out if educational level has a significant impact on extrinsic motivation of the respondents sample from the mining companies. The result revealed that there was no significant difference in the scores on extrinsic motivation with respect to the educational level of the respondents, $F(4,200)=2.788, p>0.05$. The null hypothesis was therefore rejected at $5 \%$ level of significance, meaning that further analysis could not be performed on the average scores on extrinsic motivation as the scores were almost the same across educational levels.

\subsubsection{Motivation and Age}

$H_{3}$ : There is a significant difference in motivation across age of employees in the MiningCompanies in Ghana.

\begin{tabular}{|c|c|c|c|c|c|c|}
\hline & \multicolumn{2}{|c|}{ Young Adult } & \multicolumn{2}{|c|}{ Middle Age } & \multirow[b]{2}{*}{ T-Statistics } & \multirow[b]{2}{*}{ P-value } \\
\hline & Mean & Std. D & Mean & Std. D & & \\
\hline Motivation & 21.73 & 7.54 & 22.81 & 8.22 & 0.914 & 0.362 \\
\hline
\end{tabular}

Table 8. Level of motivation of Young Adults and Middle Age (Independent T-Test)

An independent sample t-test was conducted to find out if there exist, significant difference in scores on level of motivation with respect to the young adult and the middle age. The age groups were dichotomized into two; thus young adults (20-40 years) and middle age (41-60 years) group. Results from Table 8 above indicated there was no significant difference in total 
scores on employee motivation with respect to age groups that is the young adult group $(M=21.73, S D=7.54)$ and scores for middle age group $(M=22.81, S D=8.22)$; level of motivation; $(t(200)=0.914, p>0.05)$.

This result suggests that level of motivation with respect to age groups do not differ significantly. Hence it can be concluded with a high level of confidence that employees from the four mining companies experience on the average the same level of motivation.

\section{Discussion}

\subsection{Demographic Characteristics}

The purpose of this study has been to compare employee motivation and its impact on work performance among mining companies in Ghana. These companies were AngloGold Ashanti Ltd., Goldfields Ghana Ltd., Chirano Gold Mines Ltd. and Newmont Ghana Ltd. All the managers interviewed had worked between five to ten years in their respective organizations.

Response on the gender of the participants across the mining companies indicated it continues to be a male dominated sector. The males were about 73 percent of the sample $(n=145)$ and the females were about 28 percent of sample $(n=55)$. This is not purely for social reasons, such as stereotypes but women participation in the mining industry has been discouraged through legislation. Formerly, in South Africa, legal barriers prevented women from working underground (South African Minerals Act, 1991). The introduction of the South African Mining Charter in 2002 was however instituted to address the imbalance. This is also seen in the Ghanaian mining industries where workers who go underground; artisanal miners, and operational roles ranging from miners to tractor operators and plant managers are handled by men and the administrative part handled mostly by women (Tsikata, 1997).

The study also revealed that majority of the participants were those between the age group 20-40 years representing about 69 percent of the sample $(n=137)$ followed by those between the age group 41-60 years also representing about 32 percent of the sample $(n=63)$. For the purpose of the study, the age groups were dichotomized into young adults made up of participants within the age range $20-40$ years and the middle age also made up of participants within the age range of 41-60 years as shown earlier in the study.

This implies that the young adults are energetic and with a little effort, they can perform very well in terms of productivity as indicated by one of the interviewees. Based on that, the young adults are granted the opportunity to work in the mining industries as compared with the middle age.

Educational level of participants in the mining companies revealed that, most of the employees were first degree holders representing 43 percent of the sample $(n=86)$. This was followed by 
those with diploma representing 32 percent of the sample $(n=63)$, next was those with SSSCE and below representing 11 percent of the sample $(n=21)$. Masters/PhD holders representing 9 percent of the sample $(n=17)$ and A/O Level representing 7 percent of the sample $(n=12)$ were the lowest. All the level of education was featured in order to get a holistic response and eliminate bias.

The hypotheses that were formulated based on the objectives of the study were tested and the results discussed below:

\subsection{Intrinsic Motivation and Work Performance}

$\mathbf{H}_{\mathbf{1}}$ : There is a significant relationship between Intrinsic Motivation and Work Performance

One-way analysis of variance (ANOVA) was employed to test if there exist, a significant differences in scores on intrinsic motivation in the mining sector, across levels of education of the employees as presented in Table 6, to determine the performance of employees among the four mining companies. Scores on intrinsic motivation was significantly different across levels of education of the employees, $F(4,200)=5.846, p<0.05$. With this observation, a post hoc analysis was further carried out to find where the differences exist by using the average scores on intrinsic motivation.

From Table 6, the group with the highest score on intrinsic motivation were first degree holders followed by SSSCE and below; next was A/O level holders and Masters or PhD, while the least group were respondents with diplomates. This means that in terms of level of education, employees with First degree, SSSCE and below, A/O level found the intrinsic variables more important regarding motivation than employees with Masters or Doctorate degree and Diploma.

Motivators or intrinsic factors of motivation according to Herzberg (2003) are considered as high level needs believed to include achievement, recognition, responsibility and opportunity for growth. From the various literatures that were reviewed in the early chapters of the study, it was realized that intrinsic factors cause positive job attitudes because they satisfy the worker's need for self-actualization as it is clear in the works of Maslow (1954). According to Andrew (2004), intangible or psychological rewards like appreciation and recognition plays a vital role in motivating employee and increasing performance. A study by Huddleston, Good and Frazier (2002) found that higher educated employees tended to be more powerfully motivated by intrinsic rewards such as praise and recognition, than their less educated counterparts. But this was slightly different from the quantitative findings. In the case of the qualitative, it was supported. 
The qualitative findings showed that employees who are inclined to pursue academic goals are generally more motivated by a sense of achievement and recognition because every individual feels he or she has to be appreciated when he or she performs a given task excellently. By saying "thank you" to an employee, he or she will know that his or her work is appreciated by management. Because people with a need for achievement and who experience success in this regard acquire a stronger belief and confidence in themselves, which encourages them to contribute towards the goals and objectives of the organization.

\subsection{Extrinsic Motivation and Work Performance}

$\mathbf{H}_{\mathbf{2}}$ : There is a significant relationship between Extrinsic Motivation and Work Performance

From Table 7 in the findings, a one-way analysis of variance was conducted to find out if extrinsic motivation impacts on performance by using the educational level of employees sampled from the four mining companies. The result revealed that there was no significant difference in scores on extrinsic motivation with respect to the level of educational of employees, $F(4,200)=2.788, p>0.05$.

Several studies support this finding (for example: Bhargava \& Kelkar, 2000; Gouws, 1995; Herzberg, 2003; Moon, 2000; Stinson \& Johnson, 1977).

Herzberg's two-factor theory posits that extrinsic or hygiene factors such as working conditions, company policies and administration, pay/financial benefits and interpersonal relationships with supervisors and employees do not motivate, but prevent dissatisfaction and pain. Their presence only provides the right environment for work. In Lindner's survey at the Ohio State University (Lindner, 1998) for instance, it was realized that working conditions are a primary concern of management as the working environment can determine the employees' performance and productivity. However, evidence shows that the settings in the workplace do not have a serious impact on employee performance, but they can definitely soften or harden employee behaviors (Robbins, 2000).

In an agency theory context, incentive contracts designed to encourage extrinsic motivation are held to be indispensable (Osterloh et al., 2002). Similarly, expectancy theory argues that linking incentives to performance motivates employees to increase their effort and performances (Jenkins, Mitra, Gupta \& Shaw, 1998; Lawler, 1973; Vroom, 1964) which support the qualitative findings that much emphasis was stressed on the extrinsic factors that impact on motivation leading to performance. The results revealed that, employees place much emphasis on remuneration, job security, working conditions, interpersonal relations with supervisors, subordinates and peers. For instance the need for security is one of the most 
basic needs, according to Alderfer's (1969), Maslow's (1968), and McGregor's (1960) theories. Davy, Kinicki and Scheck (1997) assert that, job security refers to an individual's expectations about continuity in a job situation, and extends to concern over loss of desirable job features such as promotion opportunities and working conditions. Though Herzberg's two-factor theory posits that extrinsic or hygiene factors do not motivate, but prevent dissatisfaction and pain, it can be argued that the presence of these extrinsic factors among mine workers leads to motivation and impacting on their performance according to the empirical findings that support that claim.

\subsection{Motivation and Age}

$\boldsymbol{H}_{3}$ : There is a significant difference in motivation across age of employees in the Mining Companies in Ghana.

An independent sample t-test was conducted to find out if there was significant difference in scores on level of motivation with respect to the age group of employees, which was dichotomized into young adults (20-40 years) and middle age (41-60 years). The dichotomized grouping was based on Levinson's (1986) article "A Conception of Adult Development". The results as presented in Table 8 indicated that, there was no significant difference in total scores on employee motivation with respect to the age groups; that is the young adult $(M=21.73$, $S D=7.54)$ and the middle age $(M=22.81, S D=8.22)$ level of motivation; $(t(200)=0.914$, $p>0.05)$. This suggest that the level of motivation with respect to age groups do not differ significantly as employees from the four mining companies experience on the average the same level of motivation. The result was contrary to the qualitative findings and an assertion made by Ashwathapa (2005).

According to Ashwathapa (2005), individuals experience different degree of motivation at different stages of their life which further argues that motivation is high at the initial stage, gets gradually reduced, starts rising up to certain stage, and finally dips to a low degree.

In the qualitative findings, it was revealed that as employees' age, they are less motivated, they desire to achieve and master new skills, and are less likely to compete with their colleagues than employees in their twenties and thirties. From the qualitative study it was found that young adults are more anxious to establish themselves financially as soon as possible when they are employed in the mining industry. Once they have established themselves as successful and competent, which generally happens later in their work lives, a focus shift towards a preference for retirement packages. 


\section{Conclusion and Recommendation}

The study showed that employees of the four large scale mining companies are motivated by both intrinsic and extrinsic factors with particular emphasis on pay or remuneration. Good pay was identified to be the best motivating factor for employees at the mining industry

According to Frey (1997), once pay exceeds subsistence level, intrinsic factors are stronger motivators, and staff motivation requires intrinsic rewards such as satisfaction at doing a good job and a sense of doing something worthwhile. From the study, the intrinsic factors showed a strong significant difference on the motivation which suggests that, once workers are paid very well, they will appreciate the intrinsic factors.

In measuring performance that job satisfaction tools were used, the study revealed that satisfaction of employees' leads to better performance.

Since managing human resources effectively has become fundamental for companies in $21^{\text {st }}$ Century business world, in particular in order to adapt to change (Schuler, 1998) and also to have the right people who are capable of delivering company strategies (Accel-Team, 2005), it is important for employers to put in place good strategies and the resources that employees will embrace in order to be committed to their job and makes their job look like a hobby to them. Lawler (2003) argues that prosperity and survival of organizations is determined through how they treat their human resources.

Job security was one of the issues that came up. Retirement plan and health insurance guarantee the employee's job. The qualitative study also should that, due to the risk associated with the mining industry, there is still effective health and safety policy in almost all the large-scale mining companies since the state ensures that management has to put strategies in place to avert possible occupational health and safety instructions.

The study makes the following recommendations:

- The safety and health needs of staff should continued to be addressed particularly those exposed to toxic substances and harmful chemicals as well as other factors identified as affecting motivation and performance of staff. In B.F. Skinner's (1953) reinforcement theory, he states that the best way to motivate an employee is to make positive changes to the external work environment continuously and that employee behaviour that yield positive outcomes should be reinforced. The study revealed that, the level of workplace fatalities, injuries and illnesses still remains unacceptably high and takes an enormous toll on men, women and their families. There is every probability that if this theory is applied to the mining staff, staff motivation and productivity will continue to increase. 
- Employers of mining companies should constantly assess the employees' motivation levels which can be done quarterly to address the intrinsic and extrinsic factors that motivate employees. Management would therefore know the pressing need of the employees at every point in time and works towards it. Consent forms can therefore be sent to employees in the form of questionnaires and interviews.

\section{References}

Accel-Team. (2005). Employee Motivation, Motivation in the Work Place - Theory and Practice. UK.

Adams, J.S. (1965). Injustice in Social exchange. In Berkowitz, L. (Ed.). Advances in Experimental Psychology. Academic Press, New York.

Adams, J.S. (1963). Toward an Understanding of Inequity. Journal of Abnormal and Social Psychology, 67, 422-436. http://dx.doi.org/10.1037/h0040968

Agho, A.O., Mueller, C.W., \& Price, J.L. (1993). Determinants of employee job satisfaction: An empirical test of a causal model. Human Relations, 46(8), 1007-1027. http://dx.doi.org/10.1177/001872679304600806

Ajila, C., \& Abiola, A. (2004). Influence of Rewards on Workers Performance in an Organization. Journal of Social Science, 8(1), 7-12.

Akabzaa, T.M. (2009). Mining in Ghana: Implications for National Economy Development and Poverty Reduction. In B. Campbell (Ed), Mining in Africa (chapter 1). New York: Pluto Express.

Aldag, R.J., \& Kuzuhara, L.W. (2002). Organisational Behaviour and Management: An Integrated Skills Approach. South-Western: Thomson Learning.

Alderfer, C. (1972). Existence, Relatedness and Growth. New York: The Free Press.

Alderfer C.P. (1969). An empirical test of new theory of human need. Organ. Behav Hum. Perf., 4(1), 142-175. http://dx.doi.org/10.1016/0030-5073(69)90004-X

Amponsah-Tawiah, K., \& Darteh-Baah, K. (2010). Occupational Health and Safety: Key Issues and Concerns in Ghana. International Journal of Business and Social Science, 2(14), 123-124.

Amponsah-Tawiah, K., \& Dartey-Baah, K. (2011). Occupational Health and Safety: Key Issues and Concerns in Ghana. International Journal of Business and Social Science, 2, 119-126. 
Andrew, D. (2004). The Effect of Congruence of Leadership Behaviors on Motivation, Commitment, and Satisfaction of College Tennis Players, Doctor of Philosophy These. Available online at: http://www.google.com/advance research/leadership

Andrew, D., \& Kent, R. (2007). The Impact of Perceived Leadership Behaviors on Satisfaction, Commitment, and Motivation: An Expansion of the multidimensional model of Leadership. International Journal of Coaching Science, 1(1), 35-56.

Armstrong, M. (1999). Personnel Management. Prague: Grada Publishing.

Armstrong, M. (2010). A Handbook of Human Resource Management Practice. $10^{\text {th }}$ ed. Kogan Page: London.

Arnold, J., Robertson, I.T., \& Cooper, C.L. (1991). Work Psychology: Understanding human behaviour in the workplace. London: Pitman

Arvey, R.D., Carter, G.W., \& Buerkley, D.K. (1991). Job satisfaction: Dispositional and situational influences. International Journal of Industrial and Organizational Psychology, 6, 359- 383.

Aryee, B.N.A. (2001). Ghana's mining sector: Its contribution to the national economy. Resources Policy, 27, 61-67. http://dx.doi.org/10.1016/S0301-4207(00)00042-8

Ashwathapa, K. (2005). Human Resource Management (5th ed.). Tata: McGraw Hills.

Baron, R.A. (1983). Behaviour in organizations. New York: Allyn \& Bacon, Inc.

Bedeian, A.G. (1993). Management. 3rd.ed. New York: Dryden Press.

Benabou, R., \& Tirole, J. (2006). Incentives and Prosocial Behaviour. American Economic Review, 96(5), 1652-1678. http://dx.doi.org/10.1257/aer.96.5.1652

Bhargava, S., \& Kelkar, A. (2000). Prediction of job involvement, job satisfaction and empowerment from organizational structure and corporate culture. Psychological Studies, 45(1-2), 43-50.

Bhattacharyya, D.K. (2009). Human Resource Research Methods. 2nd ed. New Delhi: Excel Books.

Bhattacharyya, D.K. (2007). Human Resource Research Methods. New Delhi: Oxford University Press.

Bishop, J. (1987). The Recognition \& Reward of Employee Performance. Journal of Labour Economics, 5(4), 36-56. http://dx.doi.org/10.1086/298164 
Blanchflower, D.G., \& Oswald, A.J. (1999). Well-Being, Insecurity and the Decline of American Job Satisfaction. Working Paper University Warwick, Dartmouth College, USA and National Bureau of Economic Research Department, University of Warwick, UK. Available online at: http://www.dartmouth.edu (Last access date: April 5th, 2012).

Bloch, R., \& Owusu, G. (2011). Linkages in Ghana's Gold Mining Industry: Challenging the Enclave Thesis, Making the Most of Commodities Programme (MMCP), Discussion Paper (1), 16.

Bratton, J., \& Gold, J. (2007). Human Resource Management: Theory and Practice (4th ed.). London: Palgrave Macmillan.

Bryan, C. \& Sell, L. (2011). Job Satisfaction, Work Environment, and Rewards: Motivational Theory Revisited. Labour, 25(1), 1-23. http://dx.doi.org/10.1111/j.1467-9914.2010.00496.x

Butkus, R.T., \& Green, T.B. (1999). Motivation, beliefs and Organizational Transformation. Organizational Quorum Books.

Cameron, J., \& Pierce, W.D. (2002). Rewards and intrinsic motivation: Resolving the controversy. Westport, CT: Bergin \& Garvey.

Carraher, R., Gibson, A., \& Buckley, R (2006). Compensation in the Baltic and the USA. Baltic Journal of Management, 1, 7-23. http://dx.doi.org/10.1108/17465260610640840

Carrel, M.R., \& Dittrich, J.E. (1978). Equity Theory: The Recent Literature, Methological Considerations and New Directions. Academy of Management Review, 3(2), 202-210.

Caruth, D.L., \& Handlogten, G.D. (2002). Compensating Sales Personnel, The American Salesman, 6-15.

Chris, A., \& Awonusi, A. (2004). Influence of Rewards on Workers Performance in an Organization. Journal of Social Science, 8(1), 7-12.

Clark, A.E. (1997). Job Satisfaction and Gender: Why are women so Happy at Work? Labour Economics, 4(4), 341-372. http://dx.doi.org/10.1016/S0927-5371(97)00010-9

Clark, A.E. (2001). What really matters in a job? Hedonic measurement using quit data. Labour Economics, 8(2), 223-242. http://dx.doi.org/10.1016/S0927-5371(01)00031-8

Clark, A.E., \& Oswald, A.J. (1996). Satisfaction and Comparison Income. Journal of Public Economics, 61(3), 359-382. http://dx.doi.org/10.1016/0047-2727(95)01564-7

Coakley, G.J. (1999). The minerals industry of Ghana, in the US Department of the Interior, US Geological Survey. Minerals Yearbook. Area Reports: International 1997, Africa and the Middle East, Volume III. 
Cole, G.E. (1996). Management Theory and Practice. 5th ed. D.P. Publications.

Coolican, H. (1999). Research Methods and Statistics in Psychology. 2nd edition. Paperback.

Cranny, C.J., Smith, P.C., \& Stone, E.F. (1992). The construct of job satisfaction. In C.J. Cranny, P.C. Smith \& E.F. Stone (eds.), Job Satisfaction: How People Feel about Their Jobs and how it Affects Their Performance. New York: Lexington Books.

Daft, R.L. (2003). Management. 6th ed. Thomson Learning.

Dartey-Baah, K. (2010). Job Satisfaction and Motivation: Understanding its impact on employee commitment and organisational performance. Academic Leadership: The Online Journal, 8(4), 4-9.

Davy, J.A., Kinicki, A.J., \& Scheck, C.L. (1997). A test of job security's direct and mediated effects on withdrawal cognitions. Journal of Organizational Behavior, 18, 323-349. http://dx.doi.org/10.1002/(SICI)1099-1379(199707)18:4<323: :AID-JOB801>3.0.CO;2-\#

Deci, E.L., \& Ryan, R.M. (1985). Intrinsic Motivation and Self-determination in Human Behavior. New York, NY: Plenum. http://dx.doi.org/10.1007/978-1-4899-2271-7

Deci, E.L., \& Ryan, R.M. (2008). Facilitating optimal motivation and psychological well-being across life's domains. Canadian Psychology, 49, 14-23. http://dx.doi.org/10.1037/0708-5591.49.1.14

Demoussis, M., \& Giannakopoulos, N. (2007). Exploring Job Satisfaction in Private and Public Employment: Empirical Evidence from Greece. Labour 21(2), 333-359. http://dx.doi.org/10.1111/j.1467-9914.2007.00370.x

Dermer, J.D. (1975). The interrelationship of intrinsic and extrinsic motivation. Academy of Management Journal, 18(1), 9-125. http://dx.doi.org/10.2307/255630

Dessler, G. (2003). Human Resource Management. 9th ed. Upper Saddle River, New Jersey: Prentice Hall.

Dickson, W.J. (1973). Hawthorne experiments. In Heyel, C. (Ed.). The encyclopedia of management. 2nd ed. New York: Van Nostrand Reinhold. 298-302.

Dormann, C., \& Zapf, D. (2001). Job Satisfaction: A Meta-analysis of Stabilities. Journal of Organizational Behavior, 22, 483-504. http://dx.doi.org/10.1002/job.98

Drafke, M.W., \& Kossen, S. (2002). The Human Side of Organisations. 8th ed. Upper Saddle River, New Jersey: Prentice Hall.

Dreher, G.F., \& Dougherty, T.W. (2002). Human Resource Strategy: A behavioural perspective for the general manager. Irwin, San Francisco: McGraw-Hill. 
Drummond, H. (2000). Introduction to Organisation Behaviour. New York: Oxford University Press.

Eisenberger, R., \& Cameron, J. (1996). Detrimental Effects of Reward. American Psychologist, 51(11), 1153-1166. http://dx.doi.org/10.1037/0003-066X.51.11.1153

Erez, M., \& Zidon, I. (1984). Effect of goal acceptance on the relationship of goal difficulty to performance. Journal of Applied Psychology, 66, 69-78. http://dx.doi.org/10.1037/0021-9010.69.1.69

Ferris, K.R. (1977). A Test of the Expectancy Theory of Motivation in an Accounting Environment. The Accounting Review, 52(3): 605-615.

Filipkowski, M., \& Johnson, C.M. (2008). Comparisons of Performance and Job Insecurity in Union and Non union Sites of a Manufacturing Company. Journal of Organizational Behavior Management, 28(4), 218-237. http://dx.doi.org/10.1080/01608060802454437

Forastieri, V. (2000). Women Workers and Gender Issues on Occupational Safety and Health. Geneva: International Labour Office.

Frey, B.S. (1997). On the relationship between intrinsic and extrinsic work motivation. International Journal of Industrial Organization, 15(4), 427-439. http://dx.doi.org/10.1016/S01677187(96)01028-4

Gagne, M., \& Deci, E.L. (2005). Self-determination theory and work motivation. Journal of Organizational Behavior, 26, 331-362. http://dx.doi.org/10.1002/job.322

Gallagher, W.E., \& Einhorn, H.J. (1976). Motivation Theory and Job Design. The Journal of Business, 49(3), 358-373. http://dx.doi.org/10.1086/295857

Garvin, T., Mcgee, T.K., Smoyer-Tomic, K.E., \& Aubynn, E.A. (2009). Community-company relations in gold mining in Ghana. Journal of Environmental Management, 90, 571-586. http://dx.doi.org/10.1016/j.jenvman.2007.12.014

George, J.M., \& Jones, G.R. (1997). Organizational spontaneity in context. Human Performance, 10, 153-170. http://dx.doi.org/10.1207/s15327043hup1002_6

Ghinetti, P. (2007). The Public-Private Job Satisfaction Differential in Italy. Labour, 21(2), 361-388. http://dx.doi.org/10.1111/j.1467-9914.2007.00375.x

Gilmer, B. (1961). Industrial Psychology. New York: McGraw-Hill. http://dx.doi.org/10.1037/13155000

Gouws, A. (1995). The relationship between motivation and job satisfaction of a group of information specialists). Unpublished M. Bib. dissertation. Rand Afrikaans University. 
Green, T. (2000). Motivation Management: fuelling performance by discovering what people believe about themselves and their organisations. Palo Alto: Davies-Black Publishing.

Hackman, J.R., \& Oldham, G.R. (1980). Work redesign. Readings, MA: Addison-Wesley.

Hadjimanolis, A. (2000). An Investigation of Innovation Antecedents in Small Firms in the Context of a Small Developing Country. $R$ \& D Management, 30(3), 235-245. http://dx.doi.org/10.1111/1467-9310.00174

Hafiza, S.N., Shah, S.S., Jamsheed, H., \& Zaman, K. (2011). Relationship between rewards And employee's motivation in the non-profit organizations of Pakistan. Business Intelligence Journal, 4(2), 327-329.

Hage, J., \& Dewar, R. (1973). Elite Values versus Organizational Structure in Predicting Innovation. Administrative Science Quarterly, 18(3), 279-290. http://dx.doi.org/10.2307/2391664

Harpaz, I. (1990). The Importance of Work Goals: An International Perspective. Journal of International Business Studies, 21, 75-93. http://dx.doi.org/10.1057/palgrave.jibs.8490328

Hellriegel, D., \& Slocum, J.W. (2007). Organisational Behavior. Thomson South-Western.

Heneman, R.L., Greenberger, D.B., \& Strasser, S. (1988). The relationship between pay-for-performance perceptions and pay satisfaction. Personnel Psychology, 41(4), 59-745. http://dx.doi.org/10.1111/j.1744-6570.1988.tb00651.x

Herzberg, F., Mausner, B., \& Snyderman, B.B. (1959). The motivation to work. New York: John Wiley \& Sons.

Herzberg, F. (2003). One more time: how do motivate employees? Harvard Business Review, 81, 86-96.

Hilson, G., \& Banchirigah, S.M. (2009). Are Alternative Livelihood Projects Alleviating Poverty in Mining Communities? Experiences from Ghana. Journal of Development Studies, 45(2), 172-196. http://dx.doi.org/10.1080/00220380802553057

Hilson, G.M. (2004). Structural adjustment in Ghana: Assessing the impacts of mining-sector reform. African Affairs, 54-77. http://dx.doi.org/10.1353/at.2005.0006

Hom, P., \& Griffeth, R. (1991). A structural equations modeling test of a turnover theory: Cross-sectional and longitudinal analysis. Journal of Applied Psychology, 76, 350-366. http://dx.doi.org/10.1037/0021-9010.76.3.350

Homans, G.C. (1950). The Human Group. Harcourt, Brace and World. 
House, R.J., \& Wigdor, L.A. (1967). Herzberg's dual-factor theory of job satisfaction and motivation: A review of the evidence and a criticism. Personnel Psychology, 20(4), 369-390. http://dx.doi.org/10.1111/j.1744-6570.1967.tb02440.x

Howard, J., \& Frink, D. (1996). The Effects of Organizational Restructure on Employee Satisfaction. Group and Organization Management, 21(3), 278-303.

http://dx.doi.org/10.1177/1059601196213003

Huczynski, A.A., \& Buchanan, D.A. (1991). Organizational Behaviour-An introductory text. 2nd ed. Prentice Hall (UK) Ltd. 436-466.

Huddleston, P., Good, L., \& Frazier, B. (2002). The influence of firm characteristics and demographic variables on Russian workers' work motivation and job attitudes. International Review of Retail, Distribution and Consumer Research, 12(4), 395-421. http://dx.doi.org/10.1080/09593960210151171

Igalens, J., \& Roussel, P. (1999). A Study of the relationship between Compensation package, Work motivation and Job satisfaction. Journal of Organisational Behaviour, 20(7), 1003-1025. http://dx.doi.org/10.1002/(SICI)1099-1379(199912)20:7<1003::AID-JOB941>3.0.CO;2-K

ILO (2005). Safe work. Global estimates of fatal work related diseases and occupational accidents, World Bank Regions.

Janssen, O. (2000). Job Demands, Perceptions of Effort- Reward Fairness and Innovative Work Behavior. Journal of Occupational and Organizational Psychology, 73(3), 287-302. http://dx.doi.org/10.1348/096317900167038

Jenkins, D.G. Jr., Mitra, A., Gupta, N., \& Shaw, J.D. (1998). Are financial incentives related to performance? A meta-analytic review of empirical research. Journal of Applied Psychology, 83(5), 87-777. http://dx.doi.org/10.1037/0021-9010.83.5.777

Irvine, L. (1991). Euromoney, September.

Kahya, E. (2007). The Effect of Job characteristics and working conditions on job performance. International Journal of Industrial Ergonomics, 37, 515-523.

http://dx.doi.org/10.1016/j.ergon.2007.02.006

Kohn, A. (1993). Why incentive plans cannot work. Harvard Business Review, 71(5), 54-63.

Kreitner, R. (1995). Management. 6th ed. Boston: Houghton Mifflin Company.

Kreitner, R., \& Kinicki, A. (1998). Organisational Behaviour. 4th ed. Boston: Irwin McGraw-Hill.

Kreisman, B.J. (2002). Insights Into Employee Motivation, Commitment and Retention. White Paper. Insights Denver. 
Kunz, A., \& Pfaff, D. (2002). Agency theory, performance evaluation and the hypothetical construct of intrinsic motivation. Accounting, Organizations and society, 27(3), 95-275. http://dx.doi.org/10.1016/S0361-3682(01)00031-9

Lawler, E.E. (1973). Motivation in the Workplace. Monterey, CA: Brooks/Cole Publishing.

Lawler, E.E. (2003). Treat people right. San Francisco: Jossey-Bass Inc. McGraw- Hill Irwin.

Lee, C., Law, K.S., \& Bobko, P. (1999). The importance of justice perceptions on pay effectiveness: A two-year study of a skill-based pay plan. Journal of Management, 25(6), 851-873. http://dx.doi.org/10.1177/014920639902500604

Lee, S.Y., \& Whitford, A.B. (2007). Exit, voice, loyalty, and pay: evidence from the public workforce. Journal of Public Administration Research and Theory, 18(4), 71-647. http://dx.doi.org/10.1093/jopart/mum029

Levinson, D.J. (1986). A conception of adult development. American Psychologist, 4, 3-13. http://dx.doi.org/10.1037/0003-066X.41.1.3

Lindner, J.R. (1998). Understanding employee motivation. Journal of Extension, 36(3), Research in Brief, 3RIB3.

Lindner, J.R. (2004). Understanding Employee Motivation. Journal of Extension, 36(3), 1-8.

Locke, E.A., \& Latham, G.P. (1979). A Theory of Goal-setting and Task Performance. Englewood Cliffs, NJ: Prentice Hall.

Locke, E.A., \& Latham, G.P. (2004). What Should We Do About Motivation Theory? Six recommendations for the twenty-first century. Academy of Management Review, 29(3), 388-403.

Locke, E.A., Smith, K.G., Erez, M.E., Chah, D-Ok, \& Shaffer, A. (1994). The effects of intraindividual goal conflict on performance. Journal of Management, 20, 67-91. http://dx.doi.org/10.1177/014920639402000104

Malhotra, N.K. (2007). Marketing Research: An Applied Approach. 3rd ed. Pearson Education. http://dx.doi.org/10.1108/S1548-6435(2007)3

Marshall, C., \& Rossman, G.B. (1995). Designing qualitative research (2nd ed.). Thousand Oaks, California: Sage.

Maslow, A.H. (1954). Motivation and Personality. New York, NY: Harper \& Row.

Maslow, A.H. (1968). Some educational implications of the humanistic. Psychologies, Harvard Educational Review, 38, 85-696. http://dx.doi.org/10.17763/haer.38.4.j07288786v86w660 
Mathieu, J.L. (1991). A cross-level nonrecursive model of the antecedents of organizational commitment and job satisfaction. Journal of Applied Psychology, 76, 607-618. http://dx.doi.org/10.1037/0021-9010.76.5.607

McCullagh, P. (2005). Sport and Exercise Psychology Lecture. Cal State University East Bay. $10 / 27$.

McGregor, D. (1960). The human side of enterprise. New York, 21.

Mohammad, J., Habib, F.Q., \& Zakaria, S. (2010). Organizational citizenship behavior and commitment: Do age and tenure make any difference?. Business \& Management Quarterly Review, 1(3), 28-49.

Mol, A. (1992). Motivating subordinates. IPM Journal, 11(2), 19-22.

Moon, M. (2000). Organizational Commitment Revisited in New Public Management: Motivation, Organizational Culture, and Managerial Level. Public Performance and Management Review, 24(2), 94-177. http://dx.doi.org/10.2307/3381267

Moynihan, D.P., \& Pandey, S.K. (2007). Finding workable levers over work motivation: Comparing job satisfaction, job involvement, and organizational commitment. Administration \& Society, 39(7), 803-832. http://dx.doi.org/10.1177/0095399707305546

Mullins, L.J. (2010). Management and Organisational Behaviour. 10th ed. Harlow, FT Prentice Hall.

Mumford, M.D. (2000). Managing Creative People: Strategies and Tactics for Innovation. Human Resource Management Review, 10(3), 313-351. http://dx.doi.org/10.1016/S10534822(99)00043-1

Nabi, G.R. (2000). Motivational Attributes and Organizational Experiences as Predictors of Career-enhancing Strategies. Career Development International, 5(2), 91-98. http://dx.doi.org/10.1108/13620430010318963

Nyanteng, V.K. (1997). Policies and Options for Ghanaian Economic Development. Legon: ISSER.

Ogola J.S., Mutuilah W.V., \& Omulo M.A. (2002). Impacts of gold mining on the environment and human health: A case study in the Migori Gold Belt, Kenya. Environmental Geochemistry and Health, 24(2), 141-158. http://dx.doi.org/10.1023/A:1014207832471

Osterloh, M., Frost, J., \& Frey, B.S. (2002). The dynamics of motivation in new organizational forms. International Journal of the Economics of Business, 9(1), 61-77. 
Ostroff, C. (1992). The relationship between satisfaction, attitudes, and performance: An organizational Level Analysis. Journal of Applied Psychology, 77, 963-974. http://dx.doi.org/10.1037/0021-9010.77.6.963

Page, L. (2008). Do not show me the money? The growing popularity of non-monetary incentives in the workplace. Available at: http://www.oppapers.com/essays/Non-moneatry-incentivesworkplaces/155356 (Accessed: August 2011).

Palmer, B. (2005). Practical Advice for HR Professionals: Create individualized Motivation Strategies. Melcrum Publishing Ltd.

Pearson, R. (1991). The human resource: Managing people and work in the 1990s. Berkshire: McGrawHill.

Pool, S.W. (1997). Relationship of Job Satisfaction with Substitutes of Leadership, Leadership Behavior, and Work Motivation. The Journal of Psychology, 131(3), 271-283. http://dx.doi.org/10.1080/00223989709603514

Porter, L.W., \& Lawler, E.E. (1968). Managerial Attitudes and Performance. Irwin-Dorsey, Homewood, Illinois.

Porter, L.W., \& Steers, R.M. (1973). Organizational, work, and personal factors in employee turnover and absenteeism. Psychological Bulletin, 80, 151-176. http://dx.doi.org/10.1037/h0034829

Punch, K.F. (2003). Survey Research: The Basics. London: Sage Publications Ltd.

Ramlall, S. (2004). A Review of Employee Motivation Theories and Their Implications for Employee Retention within Organisations. The Journal of American Academy of Business, $5(20), 52-63$.

Reio, G.T., \& Callahon, J.L. (2004). Affect, Curiosity, and Socialization-related Learning; A path analysis of antecedents to job performance. Journal of Business and Psychology, 19, 3-22. http://dx.doi.org/10.1023/B:JOBU.0000040269.72795.ce

Ren, T. (2010). Value Congruence as a Source of Intrinsic Motivation. Kyklos, 63(1), 94-109. http://dx.doi.org/10.1111/j.1467-6435.2010.00462.x

Robbins, S.P. (2000). Organizational behavior. Concepts, controversies, and applications. Upper Saddle River, New Jersey: Prentice Hall.

Robbins, S.P. (2005). Organizational behavior. Upper Saddle River, NJ: Pearson Prentice Hall.

Roberts, E.B. (1991). Entrepreneurs in High Technology: Lessons from MIT and Beyond. New York: Oxford University Press. http://dx.doi.org/10.1093/acprof:oso/9780195067040.001.0001 
Rose, M. (2001). Quantifying overall job satisfaction. Available at:

http://www.Iser.essex.ac.uk/bhps/2001/docs/pdf/papers/rose

Rothwell, R. (1992). Successful Industrial Innovation: Critical Factors for the 1990s. R\&D Management, 22(3), 221-239. http://dx.doi.org/10.1111/j.1467-9310.1992.tb00812.x

Rotter, J.B. (1966). Generalised expectations of internal versus external control of reinforcements. Psychological Monographs, 80. http://dx.doi.org/10.1037/h0092976

Ryan, R.M., \& Connell, J.P. (1989). Perceived locus of causality and internalization: examining reasons for acting in two domains. Journal of Personality and Social Psychology, 57, 749-761. http://dx.doi.org/10.1037/0022-3514.57.5.749

Ryan, R.M. \& Deci, E.L. (2000). Intrinsic and Extrinsic Motivations: Classic Definitions and New Directions. Contemporary Educational Psychology, 25, 54-67.

http://dx.doi.org/10.1006/ceps.1999.1020

Sanda, M.A., \& Adjei-Benin, P. (2011). How is the Firm Dealing with the Merger? A Study of Employee Satisfaction with the Change Process. Journal of Management and Strategy, 2(2), 28-33. http://dx.doi.org/10.5430/jms.v2n2p28

Schneider, B., \& Dachler, H.P. (1978). Stability of job descriptive index. Journal of Psychology, 63(5), 650-653. http://dx.doi.org/10.1037/0021-9010.63.5.650

Schuler, R.S. (1998). Personnel and Human Resources Management (3rd edi.). Toronto: West Publishing Company.

Scott, S.G., \& Bruce, R.A. (1994). Determinants of Innovative Behavior: A Path Model of Individual Innovation in the Workplace. Academy of Management Journal, 37(3), 580-599. http://dx.doi.org/10.2307/256701

Senge, P.M. (1992). The Fifth Discipline: The Art and Practice of the Learning Organization. London: Century Business/Doubleday.

Shah, K. \& Shah, P.J. (2010). Motivation. Available online at: http://scribd.com/doc/6564596/motivation (Last access date: November 8th, 2010).

Skinner, B.F. (1953). Science and Human Behavior. New York: Free Press.

Skinner, B.F. (1974). About behaviorism. New York: Alfred A. Knop.

Sloane, P.J., \& Williams, H. (2000). Job Satisfaction, Comparison Earnings and Gender. Labour, 14(3), 473-502. http://dx.doi.org/10.1111/1467-9914.00142 
Smith, G.P. (1994). Motivation. In Tracey, W. (Ed.). Human resources management and development handbook. 2nd ed.

Sousa-Poza, A., \& Sousa-Poza, A.A. (2000). Well-being at work: a cross-national analysis of the levels and determinants of job satisfaction. Journal of Socio-Economics, 29, 38-517. http://dx.doi.org/10.1016/S1053-5357(00)00085-8

South African Minerals Act (1991). Minerals Act 50 of 1991. Available online at: http://www.lawsoc.co.za/members/legalresources/usefulleg/minera

Spector, P.E (2000). Industrial and Organisational Psychology: research and practice. 2nd ed. Chichester: John Wiley \& Sons, Inc.

Steers, R.M., \& Shapiro, D.L. (2004). The Future of Work Motivation Theory. Academy of Management Review, 29(3), 379-385. http://dx.doi.org/10.5465/amr.2004.13670978

Stinson, J.E., \& Johnson, T.W. (1977). Tasks, individual differences, and job satisfaction. Industrial Relations, 16(3), 315-325. http://dx.doi.org/10.1111/j.1468-232x.1977.tb00098.x

Tang, T.L., Chiu, R.K., \& Luk, V.W. (2002). Retaining and motivating employees: compensation preferences in Hong Kong and China. Personal Review, 31(4), 402-431. http://dx.doi.org/10.1108/00483480210430346

Taylor, F.W. (1911). Principles of Scientific Management. New York and London: Harper \& Brothers.

The World Bank (1992). Strategy for African Mining. World Bank Technical Paper, 181, African Technical Department series.

Tietjen, M.A., \& Myers, R.M. (1998). Motivation and Job Satisfaction. Management Decision, 36(4), 226-231. http://dx.doi.org/10.1108/00251749810211027

Torrington, D., Hall, L., \& Taylor, S. (2008). Human Resource Management. Harlow: Pearson Education Ltd.

Tosi, H.L., Mero, N.P., \& Rizzo, J.R. (2000). Managing Organizational Behaviour. Cambridge, Massachusetts: Blackwell.

Tsikata, F.S (1997). The Vicissitudes of Mineral Policy in Ghana. Resources Policy, 23(1/2), 9-14. http://dx.doi.org/10.1016/S0301-4207(97)00006-8

Tsui, A.S., Egan, T.D., \& O 'Reilly, C.A. (1992). Being different: Relational demography and organizational attachment. Administrative Science Quarterley, 37, 549-579. http://dx.doi.org/10.2307/2393472 
Vroom, V. (1964). The motivation to work. New York: John Wiley.

Warr, M. (1998). Life Course Transitions and Distance from Crime. Criminology, 36, 183-218. http://dx.doi.org/10.1111/j.1745-9125.1998.tb01246.x

Wheelan, S.A. (2010). Creating effective teams - A guide for members and leaders. Thousand Oaks, USA: Sage Publications.

WHO (1994). Global strategy on occupational health for all: The way to health at work. Geneva.

Williams, S.D. (2004). Personality, Attitude, and Leader Influences on Divergent Thinking and Creativity in Organizations. European Journal of Innovation Management, 7(3), 187-204. http://dx.doi.org/10.1108/14601060410549883

Wilson, G. (2010). The effects of external rewards on intrinsic motivation. Available at: http://www.abcbodybuilding.com/rewards.pdf (Last access date: November, 2010).

Wittmer, D. (1991). Serving the people or serving for pay: Reward preferences among government, hybrid sector, and business managers. Public Productivity and Management Review, 14(4), 369-383. http://dx.doi.org/10.2307/3380953

Wright, T.A., \& Bonett, D.G. (1992). The effect of turnover on work satisfaction and mental health: Support for a situational perspective. Journal of Organizational Behavior, 13, 603-615. http://dx.doi.org/10.1002/job.4030130606

Wright, B.E., \& Kim, S. (2004). Participation's influence on job satisfaction: The importance of job satisfaction: The importance of job characteristics. Review of Public Personnel Administration, 24(1), 18-40. http://dx.doi.org/10.1177/0734371X03259860

Zikmund, W. (2003). Marketing Research, USA: Thompson South-Western.

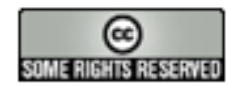

Article's contents are provided on an Attribution-Non Commercial 3.0 Creative commons license. Readers are allowed to copy, distribute and communicate article's contents, provided the author's and Journal of Industrial Engineering and Management's names are included. It must not be used for commercial purposes. To see the complete license contents, please visit http://creativecommons.org/licenses/by-nc/3.0/. 